\title{
Medicinal Plants, Phytochemicals, and Herbs to Combat Viral Pathogens Including SARS-CoV-2
}

\author{
Arumugam Vijaya Anand ${ }^{1, *}$, Balasubramanian Balamuralikrishnan ${ }^{2,+} \mathbb{D}$, Mohandass Kaviya ${ }^{1}$, \\ Kathirvel Bharathi ${ }^{1}$, Aluru Parithathvi ${ }^{1}$, Meyyazhagan Arun ${ }^{3}$, Nachiappan Senthilkumar 4 , \\ Shanmugam Velayuthaprabhu ${ }^{5}$, Muthukrishnan Saradhadevi ${ }^{6}$, Naif Abdullah Al-Dhabi ${ }^{7}$, \\ Mariadhas Valan Arasu ${ }^{7,8}$, Mohammad Iqbal Yatoo ${ }^{9}$, Ruchi Tiwari ${ }^{10}{ }^{(D)}$ and Kuldeep Dhama ${ }^{11, *(D)}$
}

Citation: Anand, A.V.;

Balamuralikrishnan, B.; Kaviya, M. Bharathi, K.; Parithathvi, A.; Arun,

M.; Senthilkumar, N.;

Velayuthaprabhu, S.; Saradhadevi, M.; Al-Dhabi, N.A.; et al. Medicinal Plants, Phytochemicals, and Herbs to Combat Viral Pathogens Including SARS-CoV-2. Molecules 2021, 26, 1775. https://doi.org/10.3390/molecules 26061775

Academic Editor: Elisa Ovidi

Received: 17 February 2021

Accepted: 18 March 2021

Published: 22 March 2021

Publisher's Note: MDPI stays neutral with regard to jurisdictional claims in published maps and institutional affiliations.

Copyright: (C) 2021 by the authors. Licensee MDPI, Basel, Switzerland. This article is an open access article distributed under the terms and conditions of the Creative Commons Attribution (CC BY) license (https:/ / creativecommons.org/licenses/by/ $4.0 /)$.
1 Medical Genetics and Epigenetics Laboratory, Department of Human Genetics and Molecular Biology, Bharathiar University, Coimbatore 641046, India; kaviyamohandass@gmail.com (M.K.); bharathikathir30@gmail.com (K.B.); parithathvialuru98@gmail.com (A.P.)

2 Department of Food Science and Biotechnology, College of Life Science, Sejong University, Seoul 05006, Korea; bala.m.k@sejong.ac.kr

3 Department of Life Sciences, CHRIST (Deemed to be University), Bengaluru 560029, India; arun47biotech@gmail.com

4 Institute of Forest Genetics and Tree Breeding (IFGTB), Forest Campus, Cowley Brown Road, RS Puram, Coimbatore 641002, India; senthilnk@icfre.org

5 Department of Biotechnology, Bharathiar University, Coimbatore 641046, India; velayuthaprabhu@yahoo.com

6 Department of Biochemistry, Bharathiar University, Coimbatore 641046, India; saradhadevi@buc.edu.in

7 Department of Botany and Microbiology, College of Science, King Saud University, P.O. Box 2455, Riyadh 11451, Saudi Arabia; naldhabi@ksu.edu.sa (N.A.A.-D.); mvalanarasu@gmail.com (M.V.A.)

8 Xavier Research Foundation, St. Xavier's College, Palayamkottai, Thirunelveli 627002, India

9 Faculty of Veterinary Sciences and Animal Husbandry, Sher-E-Kashmir University of Agricultural Sciences and Technology of Kashmir, Shalimar, Srinagar 190006, India; iqbalyatoo@gmail.com

10 Department of Veterinary Microbiology and Immunology, College of Veterinary Sciences, UP Deen Dayal Upadhayay Pashu Chikitsa Vigyan Vishwavidyalay Evum Go-Anusandhan Sansthan (DUVASU), Mathura 281001, India; ruchi.vet@gmail.com

11 Division of Pathology, ICAR-Indian Veterinary Research Institute, Izatnagar, Bareilly 243122, India

* Correspondence: avahgmb@buc.edu.in (A.V.A.); kdhama@rediffmail.com (K.D.)

+ These authors contributed equally to this work.

Abstract: The coronavirus disease 2019 (COVID-19) pandemic, caused by severe acute respiratory syndrome corona virus-2 (SARS-CoV-2), is the most important health issue, internationally. With no specific and effective antiviral therapy for COVID-19, new or repurposed antiviral are urgently needed. Phytochemicals pose a ray of hope for human health during this pandemic, and a great deal of research is concentrated on it. Phytochemicals have been used as antiviral agents against several viruses since they could inhibit several viruses via different mechanisms of direct inhibition either at the viral entry point or the replication stages and via immunomodulation potentials. Recent evidence also suggests that some plants and its components have shown promising antiviral properties against SARS-CoV-2. This review summarizes certain phytochemical agents along with their mode of actions and potential antiviral activities against important viral pathogens. A special focus has been given on medicinal plants and their extracts as well as herbs which have shown promising results to combat SARS-CoV-2 infection and can be useful in treating patients with COVID-19 as alternatives for treatment under phytotherapy approaches during this devastating pandemic situation.

Keywords: COVID-19; medicinal plants; phytochemicals; herbs; antiviral agents; SARS-CoV-2

\section{Introduction}

The severe acute respiratory syndrome coronavirus-2 (SARS-CoV-2) causing coronavirus disease 2019 (COVID-19) has become a major pandemic, which has rapidly spread to more than 215 countries, causing serious global health concerns, panic, and huge economic 
losses [1]. The virus has caused nearly 2.6 million deaths, and 117 million are affected as of 10 March 2021. Lack of specific treatment against SARS-CoV-2 has rendered the world helpless hence various countries are exploring phytochemicals obtained from medicinal plants and herbs as alternatives for treating COVID-19 patients via phytotherapy approaches [2-6]. Recent publications on SARS-CoV-2/COVID-19 suggest that phytochemicals used to treat the human immunodeficiency virus (HIV) infection can be explored for COVID-19 treatment [7]. Some of the most promising small plant molecules found to inhibit coronavirus are conjugated with fused ring structures and are classified as polyphenols [8]. In an in silico study conducted with SARS-CoV-2 main protease $\left(\mathrm{M}^{\text {pro }}\right)$ and angiotensin-converting enzyme 2 (ACE2) as targets in treating coronavirus infection, it was found that absinthin, quercetin 3-glucuronide-7-glucoside, and quercetin 3-vicianoside have a good binding potential to these targets [9]. Therefore, reliable and detailed knowledge of the structure of SARS-CoV-2 and pathogenesis of COVID-19 and also of plant phytochemicals will help us find a treatment to this coronavirus. SARS-CoV-2 has certain important factors that affect its virulence: the spike proteins that mediate its entry into the host, the nucleocapsid that protects its genetic material, and the RNA through which the virus replicates in the host [10]. There are various plants, including Glycyrrhiza glabra, Azadirachta indica, Andrographis paniculata, Calotropis gigantea, Ocimum sanctum, Curcuma longa, Withania somnifera, Zingiber officinale, Allium sativum, Tinospora cordifolia, Moringa oleifera, and others, that have anti-viral and immunomodulatory properties [11-13]. Plant-specific compounds, such as lignans, saponins, alkaloids, kaempferol, luteolin, apigenin, baicalin, quercetin, catechins, flavonoids, and polysulphates (sulphated polysaccharides) play various roles in inhibiting viral entry, destroying the nucleocapsid and genetic material, and inhibiting the replication of viruses, which includes, dengue, herpes simplex virus (HSV), hepatitis C virus (HCV), influenza, chikungunya, SARS, and others [13]. This review discusses the structure of SARS-CoV-2 and its pathogenesis, which will help understand its mechanism of infection. It presents collective information on various plants and their phytochemicals as well as potent herbs that have already been identified as potent antiviral agents against important human pathogens along with their promising applications to safeguard against SARS-CoV2 infection and usefulness in treating COVID-19 patients as alternative and complementary phytotherapy approaches.

\section{Structure and Pathogenesis of SARS-CoV-2}

SARS-CoV-2 has a positive-sense, single-stranded RNA that is associated with nucleoproteins present in its capsid comprising matrix proteins [14]. The envelope is made up of club-shaped glycoprotein projections and few coronaviruses have hemagglutinin esterase (HE)-protein [15] in their envelope. SARS-CoV-2 contains four different structural proteins: the spike (S), envelope (E), membrane $(\mathrm{M})$, and nucleocapsid $(\mathrm{N})$ proteins, which is encoded by open reading fragments located on one-third of the genome near the $3^{\prime}$ terminal. Apart from the main structural proteins, it also has other structural and accessory proteins (HE, $3 \mathrm{a} / \mathrm{b}$ protein, and $4 \mathrm{a} / \mathrm{b}$ protein) that play various roles in the replication and genome maintenance $[16,17]$. The membrane glycoprotein $(\mathrm{M})$ is the most common structural protein and it covers the membrane bilayer. It has a short $\mathrm{NH}_{2}$-domain situated on the outside and a long - $\mathrm{COOH}$ terminal located within the virion [15]. The spike protein plays an important role as an inducer of neutralizing antibodies and also acts as a type I membrane glycoprotein along with peplomers. Figure 1 depicts the structure of SARS-CoV-2.

SARS-CoV-2 enters the host through binding of its spike proteins to ACE2 receptors, and this process is primed with the help of a protease called TMPRSS2 [18,19]. After entry, the virus gets uncoated and starts genome replication and translation at the cytoplasmic membrane with the help of a coordinated process of RNA synthesis (continuous and discontinuous) mediated by a complex of the protein encoded by $20 \mathrm{~kb}$ replicase gene [20]. The coronaviruses have a replicase enzyme that is not found in other RNA viruses, with the presence of the putative sequence-specific endoribonuclease, $3^{\prime}$-to- $5^{\prime}$ exoribonucleases, $2^{\prime}$-o-ribo 
methyltransferases, and ADP-ribose-1'-phosphatase [21] The mechanism of pathogenesis is represented in Figure 2.

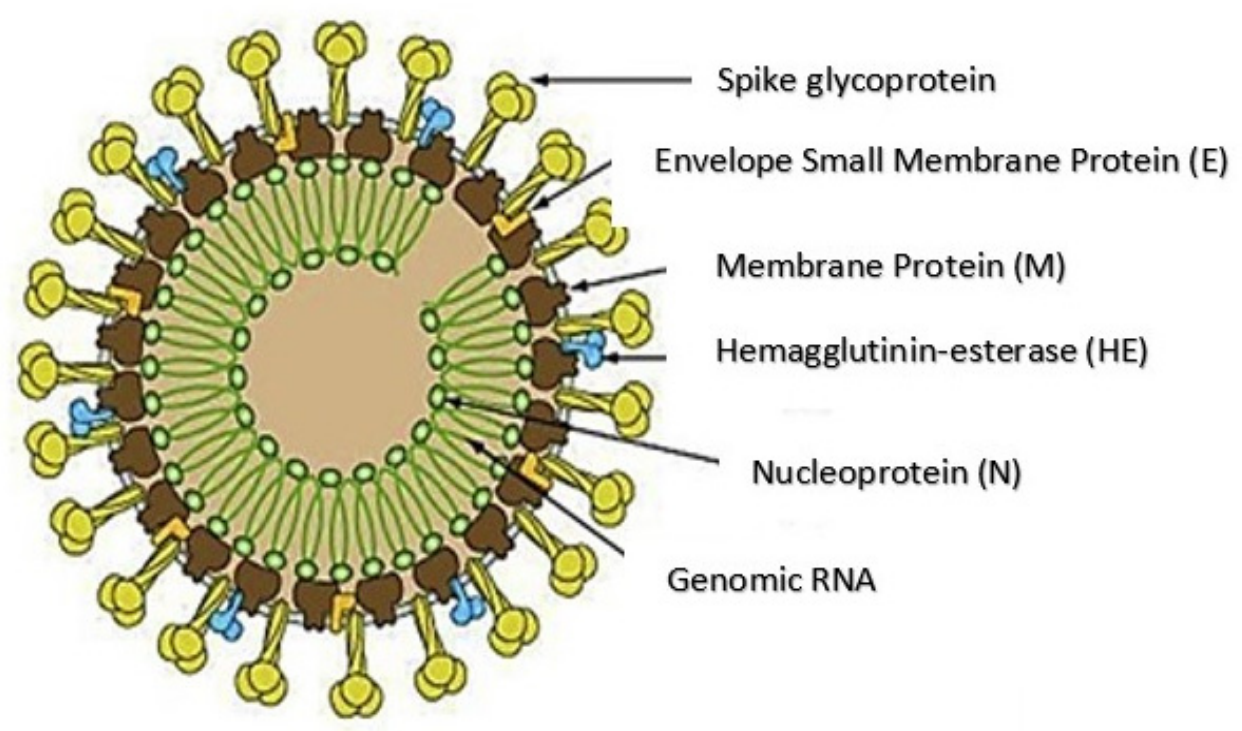

Figure 1. Structure of COVID-19 [Source: http://ruleof6ix.fieldofscience.com/2012/09/a-newcoronavirus-should-youcare html (accessed on 20 June 2020)].

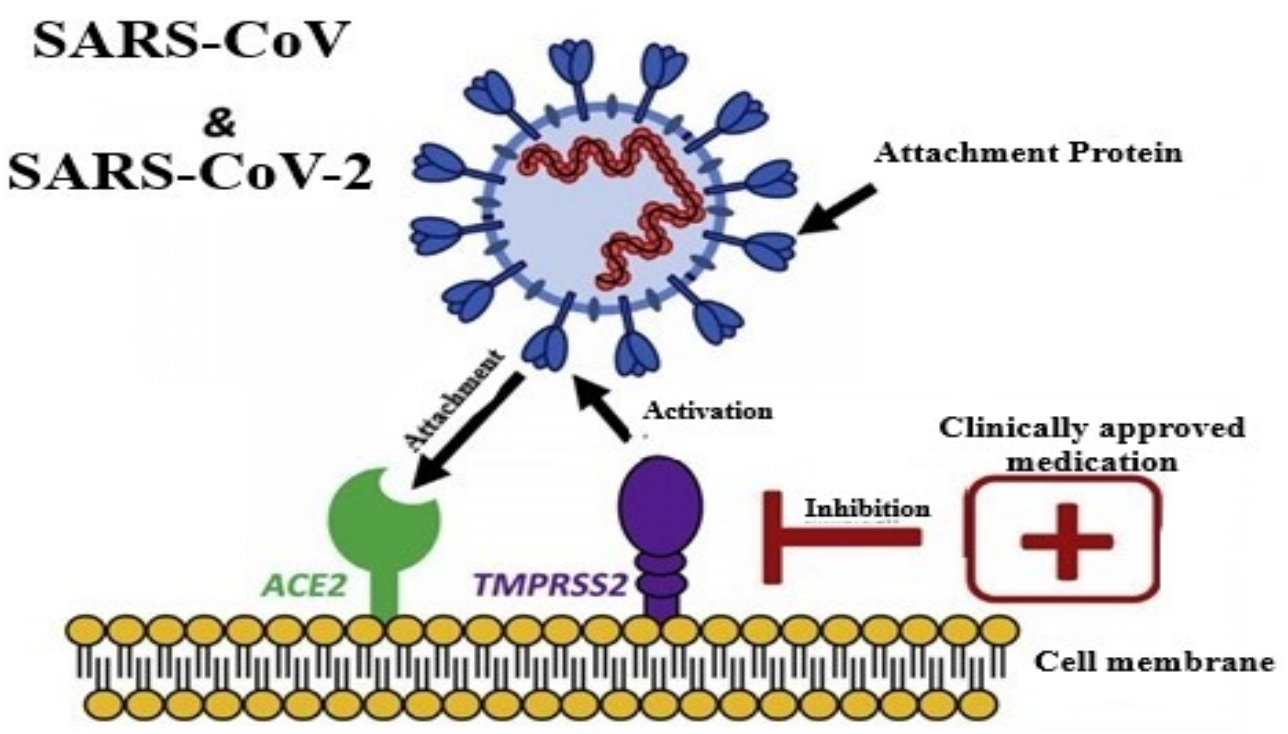

Host Cell

Figure 2. Pathology of COVID-19 [Source: Leila Mousavizadeh, Sorayya Ghasemi, Genotype and phenotype of COVID-19: Their roles in pathogenesis. Journal of Microbiology, Immunology and Infection. 2020].

\section{Similarities of Viruses to SARS COV-2}

The idea of SARS-CoV-2 structure and pathology will help in comparing viruses that share certain similarities. The zika virus is a single-stranded positive-sense RNA virus with nucleocapsid, the open reading frames codes a single protein which is processed into the capsid, membrane protein, and envelope structural proteins [22]. The rabies virus belongs to the RNA viruses. Although it is a negative RNA virus it has the lipid bilayer membrane covered with transmembrane glycoprotein spikes and a nucleocapsid that covers its genetic material [23]. Dengue virus has a positive-sense RNA [24]. The H1NI (swine flu virus) also affects the respiratory tract with a minimum incubation period of 5 to 7 days and it is 
an enveloped virus with the glycoprotein spikes on the lipid bilayer membrane and also hemagglutinin on the envelope [25].

The chikungunya virus is also a spherical virus with an envelope consisting of glycoprotein spikes and a positive-sense single-stranded RNA [26]. The Ebola virus even though a tubular-shaped virus with negative-stranded RNA has a lipid bilayer membrane and glycoprotein spikes [27]. SARS-CoV2 $\mathrm{M}^{\text {pro }}$ and HCV NS3/4A protease shows similarity in three-dimensional structure and also in the arrangement of active site residues. Besides, 8 protease inhibitors of $\mathrm{HCV}$ are also capable of binding to $\mathrm{M}^{\text {pro }}$ active site suggesting that protease inhibitors of $\mathrm{HCV}$ can effectively inhibit SARS-CoV-2 protease and the replication of SARS-CoV2 [28]. Spike protein HE found in SARS-CoV2 and hemagglutinin of influenza virus has a similar function [29]. HIV has two copies of single-stranded positive-sense RNA and belonging to the retrovirus family [30]. All the above-mentioned viruses can be compared to their genetic material like RNA viruses or positive-sense RNA virus, a structure like spherical shape, glycoprotein spikes, hemagglutinin, lipid bilayer, nucleocapsid, and the site of infection with SARS CoV-2.

\section{Plants with Antiviral Properties}

Medicinal plants and herbs have shown promising anti-viral properties and multiple beneficial health applications as well as are being used as traditional practitioners to protect various health issues of humans and animals [11-13]. Since finding drugs and treatment options for coronaviruses ( $\mathrm{CoVs}$ ), the medicinal plants and their derived phytoconstituents, herbs could provide the strong base for designing and developing the novel alternative and supplementary treatment for coronavirus with exploring phytotherapy approaches. Various medicinal plants extracts, phytochemicals, and herbs have been revised and considered to be the potential anti-CoV agents especially to tackle infection with SARS-CoV-2 for effective control of COVID-19 and future drug development with the medicinal plant formulations for preventing or curing the COVID-19 and other highly infectious viral diseases [2-6,31,32].

A herbal medicine prepared by mixing washed rice water (about $85-90 \%$ ), endodermis from the roots of Ulmus pumila and Betula luminifera (about $5-10 \%$ and $4-6 \%$, respectively) is used to cure rabies and hydrophobia (one of the symptoms of rabies). This medicine does not show any side effects and is safe for consumption [33]. Pharmaceutical formulations with harmless lectins, for example, with Sambucus nigra agglutinin-I, are widely used as antiviral agents for enveloped viruses in animals and humans [34]. The lectins play an important role against the viruses by agglutinating virions and inhibiting them from binding to the cell surface of the host and also by inhibiting the replication of the viruses [11]. Researchers proved that the root extract of Boerhaavia diffusa has potential anti-hepatotoxic activity, which can also be used to treat viral hepatitis [35]. Medicinal formulations made by B. diffusa alone or in combination with other drugs were found to have antiviral activities against infections associated with the liver, respiratory tract, and heart [36]. The extract of Eclipta alba has antiviral activities against many viruses [37]. Its leaf juice is used to cure jaundice and also other ailments of the liver [38]. Besides, the aqueous extract of Euphorbia prostrate has antiviral activity against HIV-1 integrase [39].

Medicinal plants inhibit protease enzymes of the SARS-CoV-2 [2]. Many medicinal plants are believed to target the viral 3-chymotrypsin-like cysteine protease (3CL ${ }^{\text {pro }}$ ) enzyme, which is essential for replication of coronavirus [5]. Isoflavone extracted from Psorothamnus arborescens, (2S)-Eriodictyol 7-O-(6"-O-galloyl)-beta-d-glucopyranoside from Phyllanthus emblica, 3,5,7,3', 4' ,5'-hexahydroxy flavanone-3-O-beta-d-glucopyranoside from Phaseolus vulgaris, methyl rosmarinate from Hyptis atrorubens, myricitrin from Myrica cerifera, myricetin 3-O-beta-d-glucopyranoside from Camellia sinensis, amaranthin from Amaranthus tricolor and licoleafol from Glycyrrhiza uralensis are some of the potent phytochemicals against SARS-CoV-2 [5].

Selected quinones are useful in treating HSV, parainfluenza virus, HIV, and Prunella vulgaris infections. Some mannose-specific lectins are also used in treating HIV-1 infection. 
Most of the phytochemicals can be used as reverse transcriptase inhibitors, which are very important for the inhibition of viral infections [40]. Marine-derived lectins are found to possess effective antiviral properties, while plant lectins inhibit viral infections, such as H1N1, H3N2, HIV, and HCV. Lectins obtained from Galanthus nivalis are effective in treating HIV1, HIV2, and feline immunodeficiency virus. The diversity of lectins helps treat life-threatening infections, which can lead to epidemics or pandemics [41]. Plants exhibit immunomodulatory characteristics by producing pro-inflammatory cytokines as well as different types of interleukins (IL) secreted by monocytes and dendritic cells, thereby enhancing cell-mediated immunity to fight against viruses [11]. Quinine obtained from the bark of Cinchona tree has shown potential as anti-SARS-CoV-2 through its two derivatives viz., chlroquine and hydroxychloroquine [42-44]. It has been used and is presently being used for treating patients with COVID-19 infection [42-44].

Species of the Veronica genus are consumed in the form of tonics and applied as ointments to treat influenza and coughs and also used for wound healing, which is known to be inhibiting the intracellular replication of the viruses and symptomatic episodes of HSV-1 infection [45]. Studies carried out in Pakistan conclude that 106 plant species of 56 floral families are effective in treating skin diseases caused by viral infections, such as HIV, also help treat diseases, such as psoriasis, eczema, and leprosy [46]. In vivo studies in mice show that Ayurveda medicines and Chinese folk medicine use drugs and medicines that can cure viral infections, such as those caused by HIV1, HIV2, HSV, influenza virus, Ebola virus, dengue virus, and HCV [47]. Extract from seed coats of the Caryophyllaceae family shows antiviral activity against HSV and parainfluenza viruses [48].

\section{Plants of Indian Origin and Common Use}

Numerous plants of important medicinal value in Indian traditional medicine have been quoted to possess anti-SARS-CoV-2 value [3]. A. indica, Ficus religiosa, Sesbania grandiflora, M. oleifera, Avicennia marina, Terminalia bellirica, P. amarus, Hippophae rhamnoides, are few of these plants having antiviral activity, however, their therapeutic applications in COVID-19 are yet to be investigated [3].

Some spices of Indian origin have also demonstrated anti-SARS-CoV-2 activity by in silico molecular docking approach [49]. They are considered to be effective inhibitors of SARS-CoV-2 $\mathrm{M}^{\text {pro }}$ enzyme hence having an antiviral effect. However, further validation requires their effectiveness in clinical trials [49]. Common spices needing evaluation are red pepper, garlic, fenugreek, turmeric as they contain active ingredients having diverse medicinal benefits [49]. They may affect proteases [49], RNA binding [50], or envelope protein ion channel of coronaviruses; Gupta et al. [51] and Sinha et al. [52] investigated 20 different active compounds from the Glycyrrhiza (liquorice) against spike glycoprotein and non-structural protein- 15 endoribonuclease along with lopinavir and rivabirin using the in silico approach. Among the 20 compounds, glyasperin A has a high interaction of nonstructural protein-15 endoribonuclease and glycyrrhizic acid showed the ability to bind spike glycoprotein that inhibited the entry of viruses. Both these compounds were noted to have the high binding ability with the protein receptor cavity by molecular dynamics simulation study, respectively. In vitro and in vivo studies have confirmed that G. glabra shows antiviral property against SARS-related coronavirus, H5N1 influenza A virus, HIV-1, HSV, influenza A virus, and respiratory syncytial virus [53]. Glycyrrhizin interferes with oxidative stress induced by H5N1. In lung-derived A549 cells, glycyrrhizin shows inhibition of replication of H5N1 influenza A virus, and also the expression of pro-inflammatory cytokines and apoptosis induced by H5N1 [54].

The ACE-2 favors the entry of SARS-CoV-2 and also supports an anti-inflammatory pathway. Glycyrrhizin and its active metabolite glycyrrhetinic acid have anti-inflammatory activity through Toll-like receptor 4 antagonism, which may reduce the protection of the down-regulated ACE-2. Both are involved in reducing the expression of type 2 transmembrane serine protease, which is crucial for virus uptake [55]. Pan Lau et al. [56] highlighted the therapeutic uses of glycyrrhizin for the remedy of COVID-19 by a mechanism, in- 
cluding the binding with ACE-2, inhibiting thrombin, inhibiting reactive oxygen species, down-regulating pro-inflammatory cytokines, and inducing endogenous interferon (IFN). Glycyrrhizic acid is used to treat viral hepatitis and also have potential activity against other viruses, including SARS-related animal and human coronavirus. Glycyrrhizic acid is an important anti-inflammatory and immuno-active agent that exhibits both membrane and cytoplasmic effects. It makes cholesterol-dependent disorganization of lipid cores that favors the entry of the virus into the host [57]. Nimbidin, nimocinol, nimbolide, nimbinene, isomeldenin, nimbandiol, meliacinanhydride, and zafaral compounds present in $A$. indica leaves have the potential to inhibit COVID-19 $\mathrm{M}^{\text {pro }}$ [58].

The antiviral capacity of ethanolic and aqueous extracts of $O$. sanctum was examined by infecting Madin-Darby Canine Kidney (MDCK) cells with the H1N1 virus and subsequently treating them with ethanolic and aqueous extracts of $O$. sanctum; the ethanolic extract demonstrated strong antiviral activity against $\mathrm{H} 1 \mathrm{~N} 1$ at $150 \mu \mathrm{g} / \mathrm{mL}$ [59]. In silico analysis showed that luteolin-7-O-glucuronide and chlorogenic acid present in O. sanctum could covalently bind to Cys145 of M ${ }^{\text {pro }}$ of SARS-CoV-2 and may hinder the viral enzymes [60].

When HSV-1-infected vero cells were treated with T. cordifolia, it inhibited the growth of HSV by $61.43 \%$ at $10 \mathrm{TCID}_{50}$ [61]. The phytoconstituents in T. cordifolia, such asberberine, cardiofolioside $\mathrm{B}$, tinosponone, tembetarine, xanosporic acid have been reported to have a significant docking score. Among these compounds, tinosponone is an important inhibitor of $\mathrm{M}^{\text {pro }}$ of SARS-CoV-2 and also confirmed the stability of the complex by molecular dynamics simulation [62]. Phytoconstituents present in the A. sativum can reduce the expression of pro-inflammatory cytokines, such as leptin and this can play a significant role in prevention of SARS-CoV-2 virus infection [63]. Thuy et al. [64] identified eighteen active substances, which included seventeen organo-sulfur compounds from A. sativum [64]. This may interact with the amino acids of the ACE2 protein. Particularly, the allyl di and trisulfide showed strongest anti-coronavirus activity. Moreover, A. paniculata showed antiviral activity against influenza $A$. flavi viruses, chikungunya virus, HSV-1, and HIV antigen-positive H9 cells [65]. Murugan et al. [66] investigated the four phytoconstituents, including neoandrographolide, andrographolide, 14-deoxy andrographolide, and 14-deoxy 11,12-didehydro andrographolide from $A$. paniculata by targeting three non-structural proteins, papain-like proteinase and RNA-directed RNA polymerase and also with the structural protein [66]. The results of free energy suggest that neoandrographolide possesses high affinity against SARS-CoV-2 infection. Andrographolide has been noted to inhibit $\mathrm{M}^{\text {pro }}$ of SARS-CoV-2 by docking analysis [67].

The hydro-alcoholic W. somnifera root extract displayed a maximum of $99.9 \%$ inhibition of bursal disease virus in chicken embryo fibroblasts at $25 \mu \mathrm{g} / \mathrm{mL}$ in a cytopathic effect reduction assay [68-71]. Withanolides are natural constituents present in the $W$. somnifera and have been used to treat various diseases traditionally. Tripathi et al. [72] evaluated 40 phytoconstituents from $W$. somnifera. In silico approach revealed that four compounds, such as withanoside II, IV, V, and sitoinodoside IX revealed highest docking energy [72]. Further, withanoside $V$ shows hydrogen-bonding with the active site of the protein and binding affinity. Quercetin glucoside and withanoside $X$ also favor the interactions at the binding site of non-structural protein- 15 endoribonuclease and receptor-binding domain [73].

C. longa exhibited a decrease in the percentage of cell viability at higher concentrations, and reduction in viral load was observed after $24 \mathrm{~h}$ in mice infected with dengue virus [74]. The antiviral activities of curcumin, gallium-curcumin, and $\mathrm{Cu}$-curcumin were tested on HSV-1 infected Vero cell line. The cytotoxic concentration $\left(\mathrm{CC}_{50}\right)$ values for curcumin, gallium-curcumin, and Cu-curcumin were $484.2 \mu \mathrm{g} / \mathrm{mL}, 255.8 \mu \mathrm{g} / \mathrm{mL}$, and $326.6 \mu \mathrm{g} / \mathrm{mL}$, respectively, with inhibition concentration $\left(\mathrm{IC}_{50}\right)$ values of $33.0 \mu \mathrm{g} / \mathrm{mL}$, $13.9 \mu \mathrm{g} / \mathrm{mL}$, and $23.1 \mu \mathrm{g} / \mathrm{mL}$, respectively. From the results, it has been suggested that curcumin and its derivatives have antiviral activity against HSV-1 [75]. Gupta et al. [76] screened 267 compounds in C. longa by docking study [76]. The compounds C1 (1E,6E)1,2,6,7-tetrahydroxy-1,7-bis(4-hydroxy-3-methoxyphenyl)hepta-1,6-diene-3,5-dione) and 
C2 (4Z,6E)-1,5-dihydroxy-1,7-bis(4-hydroxyphenyl)hepta-4,6-dien-3-one were found to be lead agents. Both compounds have a minimum binding score against $M^{\text {pro }}$ protein when compared to lopinavir and shikonin and also efficiently bind to the catalytic part of the Mpro protein with higher efficacy.

Polyphenols of green tea [77] and withanolides of W. somnifera [72] are considered to be $M^{\text {pro }}$ inhibitors of SARS-CoV-2. Ginseng has proven antiviral, immunomodulatory, anti-inflammatory and antioxidant activity [73]. Ethanolic and aqueous leaf extracts of $M$. oleiferai have kaempferol and anthraquione. Molecular peptide docking of these compounds in comparison with hydroxychloroquine was done and both the compounds revealed important effects regarding the binding of peptides of SARS-CoV-2 [78]. An aqueous extract of the Phyllanthus species showed antiviral properties against HSV-1 and HSV-2 [38]. It was also found that Phyllanthus urinaria and P. amarus possessed significant antiviral activity against HSV-1 and HSV-2 [79]. In a study conducted in Nigeria, leaf extracts of Macaranga barteri, Ipomoea asarifolia, Mondia whitei, and Ageratum conyzoides, as well as Terminalia ivorensis bark, showed high antiviral activities against echoviruses [59]. Some Indian plants possessing antiviral properties are tabulated in Table 1 and their possible mechanisms are represented in Figure 3.

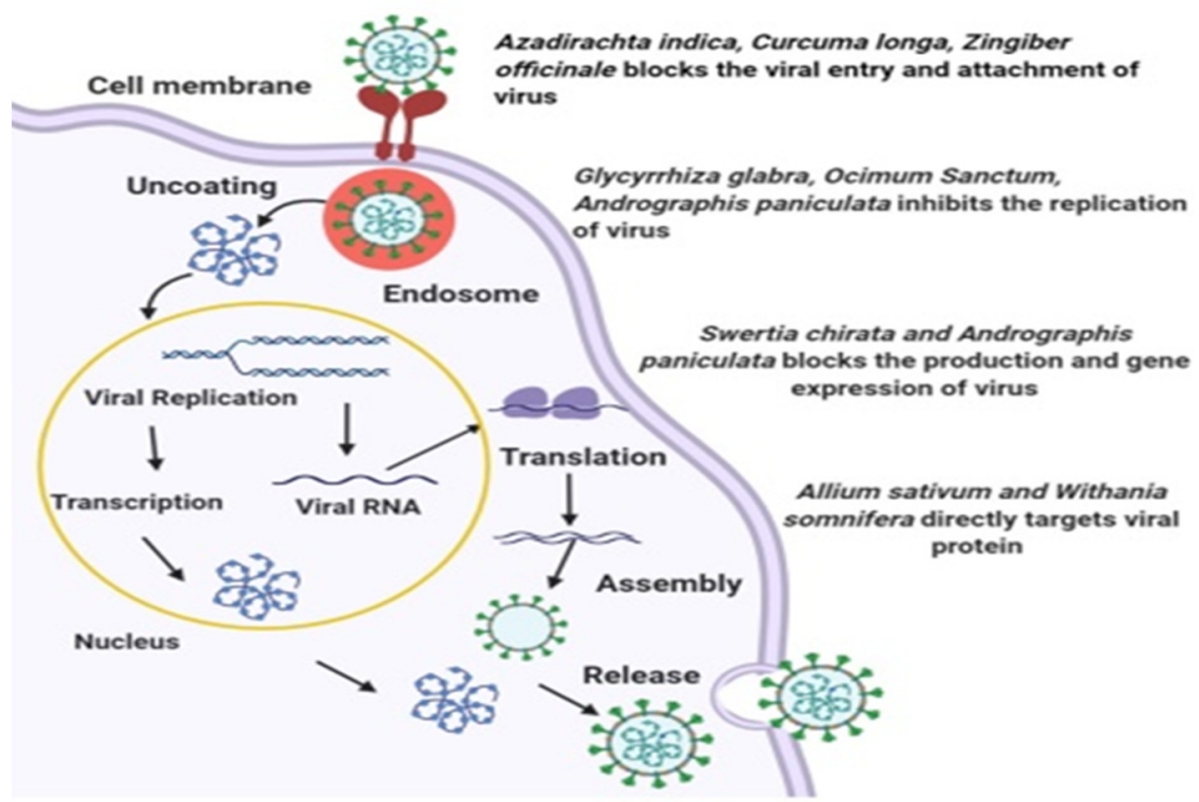

Figure 3. Possible antiviral mechanism of Indian medicinal plants. 
Table 1. Indian plants with antiviral properties.

\begin{tabular}{|c|c|c|c|c|c|}
\hline Common Name & $\begin{array}{l}\text { Botanical and } \\
\text { Family Name }\end{array}$ & Native & Parts Used & Traditional Uses & Antiviral Property \\
\hline Liquorice or Yashtimadu & $\begin{array}{l}\text { G. glabra } \\
\text { (Fabaceae) }\end{array}$ & $\begin{array}{l}\text { Central and Southern Asia, } \\
\text { Russia, Northern India } \\
\text { (Sub-Himalayan and Punjab), } \\
\text { Mediterranean, Afghanistan, and } \\
\text { Iran }\end{array}$ & Roots & $\begin{array}{l}\text { Extensively used in Indian } \\
\text { traditional medicine systems like } \\
\text { Ayurveda and Siddha for ulcer, } \\
\text { aliment, purgative, demulcent, } \\
\text { antitussive, and expectorant }\end{array}$ & $\begin{array}{l}\text { SARS-related coronavirus, H5N1 influenza } \\
\text { A virus, HCV, HIV-1. influenza A virus } \\
\text { pneumonia, respiratory syncytial virus } \\
\text { and SARS- CoV-2 }[53,55]\end{array}$ \\
\hline Neem & $\begin{array}{l}\text { A. indica } \\
\text { (Meliaceae) }\end{array}$ & $\begin{array}{l}\text { India, Bangladesh, Burma, Nepal, } \\
\text { and West Africa }\end{array}$ & $\begin{array}{l}\text { Leaves, roots, twigs } \\
\text { and seeds }\end{array}$ & $\begin{array}{l}\text { Different parts of neem are used as } \\
\text { an important ingredient in } \\
\text { Ayurveda, Unani and Homeopathy } \\
\text { medicine }\end{array}$ & Dengue virus and SARS-CoV-2 $[80,81]$ \\
\hline Green chireta & $\begin{array}{l}\text { A. paniculata } \\
\text { (Acanthaceae) }\end{array}$ & $\begin{array}{l}\text { South India, Sri Lanka, Pakistan, } \\
\text { USA, Thailand, Jamaica, and } \\
\text { West Indies }\end{array}$ & Leaves and roots & $\begin{array}{l}\text { The plant has a pivotal role in } \\
\text { Chinese and Indian (Siddha and } \\
\text { Ayurveda) traditional system for } \\
\text { different formulation against } \\
\text { various diseases diabetes, sore } \\
\text { throat, fever, cirrhosis, malaria, } \\
\text { viral hepatitis, liver cancer, and } \\
\text { upper respiratory infections }\end{array}$ & $\begin{array}{l}\text { Chikungunya virus, Influenza A, } \\
\text { Flaviviruses, HIV antigen-positive H9 } \\
\text { cells, and SARS-CoV-2 }[65,66]\end{array}$ \\
\hline Tulsi & $\begin{array}{l}\text { O. Sanctum } \\
\text { (Lamiaceae) }\end{array}$ & $\begin{array}{l}\text { India, Iran, Italy, Egypt, the USA, } \\
\text { and France }\end{array}$ & $\begin{array}{l}\text { Whole plant seeds, } \\
\text { leaves and roots }\end{array}$ & $\begin{array}{l}\text { The plant has been well } \\
\text { documented in Ayurveda, Siddha, } \\
\text { and Greek medicinal system which } \\
\text { is used for various treatment } \\
\text { purposes such as fever, common } \\
\text { cold, malaria fever, epilepsy, } \\
\text { bronchitis, migraine, headache, } \\
\text { convulsions, hepatic disease, } \\
\text { stomach disorders, and heart } \\
\text { diseases }\end{array}$ & H1N1 and SARS-CoV-2 $[59,60]$ \\
\hline
\end{tabular}


Table 1. Cont.

\begin{tabular}{|c|c|c|c|c|c|}
\hline Common Name & $\begin{array}{l}\text { Botanical and } \\
\text { Family Name }\end{array}$ & Native & Parts Used & Traditional Uses & Antiviral Property \\
\hline Turmeric & $\begin{array}{c}\text { C. longa } \\
\text { (Zingiberaceae) }\end{array}$ & $\begin{array}{l}\text { India, Nepal, China, Bangladesh, } \\
\text { and Pakistan }\end{array}$ & Rhizomes & $\begin{array}{l}\text { In Ayurveda, turmeric has a long } \\
\text { history of use because of the } \\
\text { presence of various beneficial } \\
\text { properties used in the treatment of } \\
\text { diabetic wounds, fungal infection, } \\
\text { cough, rheumatism, hepatic and } \\
\text { biliary disorder }\end{array}$ & $\begin{array}{l}\text { Dengue virus, HSV-1 and SARS-CoV-2 } \\
{[31,74]}\end{array}$ \\
\hline Ashwagandha & $\begin{array}{l}\text { W. somnifera } \\
\text { (Solanaceae) }\end{array}$ & $\begin{array}{l}\text { India, Sind, Baluchistan, } \\
\text { Afghanistan, and Sri Lanka }\end{array}$ & Roots & $\begin{array}{l}\text { The plant is well formulated in } \\
\text { Ayurveda, Siddha, Unani and } \\
\text { Tibetan Medicine system. } \\
\text { Traditionally, W. somnifera has been } \\
\text { used to treat tumor, stress, } \\
\text { immunomodulatory, depression, } \\
\text { inflammatory, adaptogenic, and } \\
\text { nervous disorder. It is also used in } \\
\text { patients with behavioural } \\
\text { disturbances for mood stabilization }\end{array}$ & HSV-1 and SARS-CoV-2 [68-71] \\
\hline Garlic & $\begin{array}{l}\text { A. sativum } \\
\text { (Alliaceae) }\end{array}$ & $\begin{array}{l}\text { Central Asia, China, } \\
\text { Mediterranean region, Mexico, } \\
\text { Egypt and in Southern and } \\
\text { Central Europe }\end{array}$ & $\begin{array}{l}\text { Cloves, flowers and } \\
\text { leaves }\end{array}$ & $\begin{array}{l}\text { Garlic has been traditionally used } \\
\text { as hypolipidemic, antihypertensive } \\
\text { and anti-thrombotic agent in } \\
\text { Ayurvedic, Chinese, and Islamic } \\
\text { medicine }\end{array}$ & $\begin{array}{l}\text { Influenza virus A and SARS-CoV-2 } \\
{[63,64,82]}\end{array}$ \\
\hline Guduchi & $\begin{array}{c}\text { T. cordifolia } \\
\text { (Menispermaceae) }\end{array}$ & Indian subcontinent and China & $\begin{array}{l}\text { Roots, stem and } \\
\text { leaves }\end{array}$ & $\begin{array}{l}\text { The plant is a common shrub used } \\
\text { as anti-allergic, anti-inflammatory, } \\
\text { antiperiodic, anti-diabetic,, and } \\
\text { anti-spasmodic properties in } \\
\text { Ayurvedic medicine }\end{array}$ & HSV-1 and SARS-CoV-2 $[62,83]$ \\
\hline Drumstick & $\begin{array}{l}\text { M. oleifera } \\
\text { (Moringaceae) }\end{array}$ & $\begin{array}{l}\text { Sub-Himalayan tracts of India, } \\
\text { Bangladesh, Pakistan, and } \\
\text { Afghanistan }\end{array}$ & $\begin{array}{l}\text { Roots, flowers, leaves } \\
\text { and pod }\end{array}$ & $\begin{array}{l}\text { The traditional use of plant } \\
\text { includes antispasmodic, } \\
\text { antiparalytic, antiviral, analgesic, } \\
\text { anti-inflammatory, antiepileptic, } \\
\text { stimulant and cardiac circulatory } \\
\text { tonic }\end{array}$ & HSV-1 and SARS-CoV-2 $[78,84]$ \\
\hline
\end{tabular}


Polysulphides are sulphates attached to a carbohydrate backbone or any other polymer. Sulphated polysaccharides have antiviral activity against viruses, especially against some enveloped viruses such as HSV in vitro $[85,86]$, human respiratory syncytial virus, cytomegalovirus, DENV-2, DENV-3, influenza A and B virus, and human hepatoma HepG2 virus. The polysulphates protect against $\mathrm{HIV}$ by shielding the $\mathrm{CD}^{4+}$ cells against the viral envelope glycoprotein (gp120) at its positively charged V3 loop, that is essential for the attachment of the virus to the primary binding site called the surface heparan sulphate before specific binding occurs through $\mathrm{CD}^{4}$ receptors [87]. This mechanism explains its antiviral activity against enveloped viruses. Therefore, it can be speculated that polysulphates might be beneficial in the case of SARS-CoV-2, which is also an enveloped virus, after performing proper investigations [85].

\section{Plant-Specific Compounds and Antiviral Mechanisms}

\subsection{Flavonoids}

Flavonoids are known for their antiviral activity. Many flavonoid compounds are well-known to act as antiviral agents by inhibiting binding and entry of viral, its replication, translation of the viral protein, the formation of envelopes using glycoproteins complexes, and virus release [88]. Flavonoids help in the signaling process in the host cell by activating gene transcription factors and also by secreting cytokines [89]. The structure-activity relationship of flavonoids shows that it is a good inhibitor of the neuraminidase enzyme of influenza virus, thereby preventing its replication [90]. Flavonoids have shown potential in therapy against COVID-19 [91]. They may inhibit SARS-CoV-2 entry into the cell [92] hence have been used in the therapy of COVID-19 patients [93].

\subsection{Catechins}

Green tea contains important catechins (polyphenols), which are of different types, such as (-)-epigallocatecheingallate (EGCG), (-)-epicatechingallate (ECG), and (-)- epogallocatechin (EGC), and has high medicinal values with health benefits [94]. In a quantitative study performed using RT-PCR, high concentrations of EGCG and ECG, but not EGC, decreased viral RNA synthesis in MDCK cells [95]. ECG and EGCG affected the activity of neuraminidase by inhibiting it more efficiently than EGC [95]. The neuraminidase enzyme in viruses is important in transporting budding viruses to other cells by cleaving the sialic acid present in glycoproteins located in the envelope. Similarly, EGCG inhibits both HSV-1 and HSV-2 by binding to their envelope proteins such as $\mathrm{gB}, \mathrm{gD}$, or other envelope proteins, which help for the fusion of the virus to cells [96]. Catechin binds the receptor-binding domain of viral S-protein, as well as ACE2 of the host, thus may serve as a therapeutic agent for COVID-19 [97]. In one of the docking analysis study, compound EGCG found in green tea revealed the highest binding affinity with S protein of SARS-CoV-2, which reflects its potential usage in preventing or treating the COVID-19 patients.

\subsection{Quercetin}

Quercetin is a flavonoid compound present in vegetables and fruits [98]. It is found to acts against the $\mathrm{HCV}$ virus by inhibiting the action of a heat shock protein that is involved in non-structural protein 5A-mediated translation of viral internal ribosome entry site, which usually occurs in response to stress [99]. Quercetin acts against HCV through the inhibition of HCV NS3 protease, which stops the replication of HCV in the sub genomic RNA replicon cell system [100]. Quercetin halts rhinovirus pathogenesis at different stages of the life cycle of the virus, including endocytosis, protein synthesis, and viral genome transcription [101]. Furthermore, quercetin, along with myricetin, quercetagetin, and baicalin, affected the growth of the Rauscher murine leukemia virus RLV [102]. Quercetin along with vitamin $C$ has been proposed to have the synergistic effect in treating COVID-19 patients [93]. Synergistic antiviral, antioxidant, and immunomodulatory activities and the ability of ascorbate to recycle quercetin, increase the effectiveness of quercetin against SARS-CoV-2 [93]. 


\subsection{Apigenin and Baicalin}

Apigenin acts against the African swine fever virus by decreasing protein synthesis, thereby causing a three-log decrease in the yield of viruses and is also effective against DNA viruses such as adenoviruses and (hepatitis B virus) HBV [103]. It shows potent antiviral effects against RNA viruses such as picornavirus and acts by inhibiting viral IRES activity, thereby inhibiting the synthesis of viral proteins $[104,105]$. The translation of enterovirus-71 is disrupted by inhibition of the association of viral RNA with transacting factors that regulate enterovirus-71 [106]. Apigenin is found to disturb HCV virus replication by decreasing the microRNA122, which is a liver-specific microRNA [107].

Baicalin acts against HBV by disrupting its DNA and viral protein synthesis [108]. In H5N1 virus infection, baicalin lowers the levels of interleukin-6 and -8 (IL-6; IL-8) produced but does not interfere with IP-10 levels [109]. Baicalin can inhibit the synthesis of human cytomegalovirus DNA and proteins; however, it does not affect the viral polymerase activity. Baicalin, by interfering with neuraminidase activity, stops the replication of H5N1 in the human lung- and monocyte-derived macrophages [109]. H1N1-infected BALB/c mice administered baicalin orally showed decreased lung virus titers and an increased mean time of death [110]. The results were also found in mice infected with Sendai virus [111]. Studies have shown that baicalin could help in the production of IFN- $\gamma$ by $\mathrm{CD}^{4+}$ and $\mathrm{CD}^{8+}$ $\mathrm{T}$ cells during infection with influenza virus [112]. In silico studies on baicalin strongly suggest that it has a good binding ability with the NS3/NS2B protein of dengue virus; however, baicalin shows better interactions with NS5 protein.

\subsection{Luteolin}

Luteolin and luteolin-rich fractions are found to have antiviral property, including SARS-CoV, chikungunya virus, Japanese encephalitis virus, and rhesus rotaviruses [113-116]. Luteolin inhibited HIV-1 by preventing clade B- and C- Tat-driven long terminal repeat (LTR) trans activation [117]. In the case of Epstein-Barr virus, luteolin deregulated the binding of transcription factor Sp1, which decreased the activity of early genes Zta and Rta [118]. Above all, it was found to be the most potent compound among 400 natural compounds against enterovirus-71 and coxsackievirus A 16 infections, since it disrupts viral RNA replication [119]. Luteolin has antiviral, anti-inflammatory, neurotrophic actions, anti-oxidant, anti-cancer, and anti-apoptotic activities [120]. It has shown the ability to inhibit the entry of SARS-CoV virus and fusion with human receptors, thus may have potential anti-SARS-CoV-2 activity [120].

\subsection{Kaempferol}

The compound kaempferol obtained from Ficus benjamina has demonstrated to have a protective effect on HSV-1 and HSV-2, except forits aglycone form [121]. A rhamnose residue containing kaempferol inhibits coronavirus release by affecting 3 a channels [122]. Kaempferol and kaempferol-7-o-glucoside display inhibitory effect on HIV 1 reverse transcriptase. Besides, kaempferol 3,7-bisrhamnoside isolated from Taxillus sutchuenensis, is effective against HCV NS3 protease function [123]. In the case of H1N1 and H9N2 influenza viruses, kaempferol affects neuraminidase activity using specific functional groups [124]. RNA frame shift site (fs RNA) is found to be the target site of kaempferol, which serves to inhibit the Japanese encephalitis virus [125]. Kaempferol has more binding stability and its structural features have shown that it affects binding at the site of N3 in the SARS-CoV-2 $\mathrm{M}^{\text {pro }}[126]$.

\subsection{Alkaloids}

Lycorine is the most important alkaloids found in the Amaryllidaceae family. The lycorine was found to inhibit the poliomyelitis virus in Vero cells at a low concentration of $1 \mu \mathrm{g} / \mathrm{mL}$ but was cytotoxic at a concentration of $25 \mu \mathrm{g} / \mathrm{mL}$ [127]. Lycorine obtained from Lycoris radiata had significant antiviral activity against two strains (BJ001, BJ006) of SARS-CoV grown on Vero cells, with an $\mathrm{EC}_{50}$ at $15.7 \pm 1.2 \mathrm{nM}, \mathrm{CC}_{50}$ at $14,980.0 \pm 912.0 \mathrm{nM}$, 
and a selective index (SI), which is greater than 900 [128]. This SI index is a ratio between the antiviral effect and the toxicity of a compound; the greater the SI value, the safer the drug could be when administered in vitro [129]. Another compound, sophoridine, was found to have antiviral activity against the Enterovirus-71, when Vero cells were pretreated with sophoridine before being infected with this virus [130]. In a study conducted with coxsackievirus in mice, sophoridine obtained from Sophora flavescens had a potential role in enhancing the expression of IFN- $\gamma$ and interleukin-10 (IL-10) to increase the host resistance response against the virus [131]. Among the ipecac, alkaloidsemetine, ipecac alkaloids and analogues are possible antiviral agents for $\mathrm{CoVs}$, hence having prospects for use in COVID-19 therapy [132].

\subsection{Saponins}

Saponin isolated from Anagallis arvensis was found to have antiviral property against poliovirus-2 and HSV-1 by protecting the host cells from structural damage [133]. Tormentic acid glucosyl ester, a triterpenoid saponin demonstrated antiviral property against HSV-1 by inhibiting its viral capsid protein synthesis and DNA replication, respectively [134]. Administration of polyphylla saponin I (obtained from Paris polyphylla, $5-10 \mathrm{mg} / \mathrm{kg}$ ) and oseltamivir $(3 \mathrm{mg} / \mathrm{kg})$ to mice infected with influenza virus decreased viral hemagglutination titers and reduced pathological conditions in lung tissues of the infected mice, thereby reducing their mortality [135]. Saponins may inhibit the cellular attachment, entry, adsorption, and penetration of a virion into the host cell. Saponins possess immunomodulatory, anti-inflammatory activities, anti-proliferative effect, and antiviral activities including SARS-CoV [4,136,137], hence may have a role in curing COVID-19 patients [136].

\subsection{Lignans}

Lignans are phenolic compounds derived from the shikimic acid biosynthetic pathway in plants [138]. Niranthin obtained from P. niruriacts acts against the HBV virus by inhibiting its antigen expression in vitro; it also inhibits duck HBV by inhibiting its DNA replication $[139,140]$. Nordihydroguaiaretic acid, found in the leaves of Larrea tridentata, shows antiviral properties against various viruses, including $\mathrm{HCV}$, dengue virus, influenza A virus, and zika virus by inhibiting genome replication and viral assembly. It affects $\mathrm{HCV}$ proliferation by altering host lipid metabolism, interfering with the lipid metabolism and it also suppresses the replication of influenza A virus [140-144]. Terameprocol, semisynthetic compound from lignin, which is derived from the leaves of L. tridentata acts against the West Nile virus by affecting viral replication against poxvirus by inhibiting the cell-to-cell transfer of the virus, and against HSV and HIV by preventing viral replication through inhibition of the binding with host transcription factor [145-149]. Arctigenin demonstrates antiviral properties including influenza A virus and HIV-1 by inducing the release of IFNs and also by inhibiting the expression of the proteins (p17 and p24) of the HIV-1 virus [150-154].

The addition of yatein, a compound obtained from the dried leaves of Chamaecyparis obtusa, to HeLa cells inhibited the expression of HSV-1ICP0 and ICP4 that arrests DNA synthesis in HSV $[155,156]$. The compound diphyllin obtained from epigeal parts of the genus Haplophyllum inhibits the vacuolar ATPase in zika virus infection; it also interferes with the downstream replication of influenza A virus to inhibit its infection [157-161]. Patentiflorin obtained from the leaves and stem of Justicia gendarussa acts against zika virus by impeding its fusion with the host cellular membrane, thus preventing infection by avoiding the acidification of lysosomal or endosomal cells of the target. This acts against HIV-1 by inhibiting its reverse transcriptase enzyme [160-164]. Clemastanin B affects viral endocytosis and ribonucleoprotein export from the nucleus while acting against influenza A virus [164-167]. Silymarin obtained from the seeds of Silybum marianum inhibits HCV production by increasing the expression of anti-inflammatory and anti-proliferative genes, but it does not affect serum albumin levels $[168,169]$. Thus, having considerable antiviral effects through the inhibition of viral replication, lipid metabolism, apoptosis, protein, and 
cytokine expression; lignins may have potent anti-SARS-CoV-2 actions as they have shown effects against SARS-CoV also [170,171].

\subsection{Tannins}

Tannins have potential in targeting viral replication at different stages like attacking their attachment, host replication process, viral particle assembly, and protein transport [172]. Ellagitannins, 1,3,4,6-tetra-O-galloyl- $\beta$-d-glucose and geraniin present in $P$. urinaria were found to be useful in suppressing the HSV-1 and HSV-2 respectively [173]. Corilagin and geraniin (ellagitannins) found in Phyllanthus amarus reduced the interaction of HIV and its replication [174]. Punicalagin and chebulagic acid, two hydrolysable tannins present in Terminalia chebula have been successful in inhibiting the viral entry and transport of virus in HSV-1 [175].

According to the study conducted with the combination of ellagitannins like castalagin, vescalagin, and grandinin with acyclovir, the effect of castalagin and vescalagin versus HSV-1 was found to be identical to acyclovir, which interpreted that the combination of ellagitannins with acyclovir was efficient $[176,177]$. Castalagin followed by vescalagin have highest activity against alphaherpevirus-1 [178]. Castalagin was also found to inhibit the HSV-1 replication with its highest sensitivity being recorded at $0-3 \mathrm{~h}$ post viral inoculation [179].

Various plants and herbs have shown effective antiviral and immune-boosting potentials against emerging viruses such as SARS-CoV, zika, ebola, nipah virus, and other highly pathogenic viruses $[8,128,166,180-183]$. Apart from developing effective vaccines, therapeutics, and antiviral drugs, the potent antiviral applications of various plants, plant extracts and herbs are required to be endorsed and proliferated optimally by strengthening researches and development activities along with conducting appropriate clinical trials and validation experiments to combat COVID-19 pandemic and its high challenges posed [12,32,184-191]. Advances in the fields of biotechnology, immunology, biochemistry, pharmacology, pharmaceuticals, and nanotechnology may be warranted to their full potential for developing successful antiviral drugs and medicines out of these safe and valuable natural resources against SARS-CoV-2 [192-200]. Beneficial applications of medicinal values of plants and herbs could lessen the high incidences, devastating scenario, and public health concerns of SARS-CoV-2/COVID-19. A summary of plant compounds and their antiviral properties is presented in Table 2 while an overview on modes of antiviral action of various phytochemicals/compounds and its derivatives are presented in Table 3 and the Figure 4 represented the antiviral properties of the plant compounds. 
Table 2. Plant compounds and their antiviral properties.

S. No

\section{FLAVONOIDS}

1.1. Catechins (Green tea) EGCG and ECG

1.2. Quercetin (C. longa)
HSV-1 and HSV-2, SARS-CoV-2

1.1. Catechins (Green tea)
EGCG and ECG

$\mathrm{HCV}$ and SARS-CoV-2

$[93,99,100]$

Enterovirus-71, foot and mouth disease virus, $\mathrm{HCV}$, African swine fever virus, and influenza A

Enterovirus, dengue virus, respiratory syncytical virus, Newcastle disease virus, HIV

and HBV
$[108,110,112,120$, 202,203] (Scutellaria lateriflora)

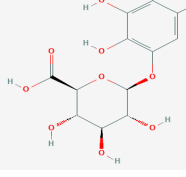

SARS-CoV-2, rhesus rota virus, chickenkuniya virus, and Japanese encephalitis virus
[113-116,120,204]

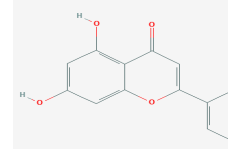

(O. sanctum)
1.6. Kaempferol (F. benjamina)
HSV-1, HSV-2, HIV, HCV,

H1NI, H9N2, Japanese encephalitis virus, and SARS-CoV-2
[121,123,124,126] 
Table 2. Cont.

S. No Name of the Compound Antiviral Property against
$\begin{aligned} & \text { 2. ALKALOIDS } \\ & \text { 2.1. Lycorine } \\ & \text { (L. radiata) }\end{aligned}$
[127,128,132,205]
(BJ001 and BJ006)

2.2. Sophoridine

(S. flavescens)

Enterovirus-71 and

$[130,131,206]$

3.

4.1. Nordihydroguairetic acid (P. niruri. L)
DENV, zika virus or West Nile virus, and influenza A virus

4.

4.2 Arctigenin (Arctium lappa)
Influenza A virus and HIV-1

[150-154,209] 
Table 2. Cont.

\section{S. No \\ Name of the Compound} obtuse)

4.3. Yatein (Chamaecyparis 4.4. Diphyllin (Genus-Haplophyllum)

\section{Structure}

Antiviral Property against

Reference

HSV-1

$[155,156]$
Zika virus and influenza A virus
4.5.Patentiflorin A

(J. gendarussa)

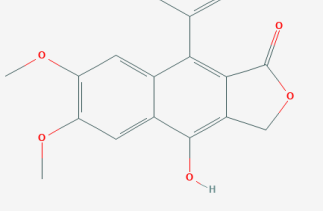

4.6. Clemastanin B (Isatis indigotica)

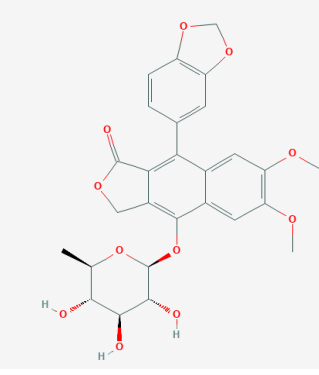

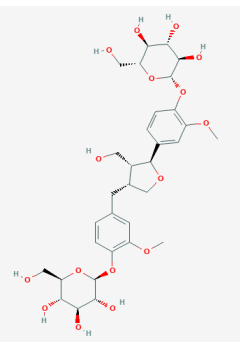

Influenza A virus

[164-167]

4.7. Silymarin C (S. marianum)

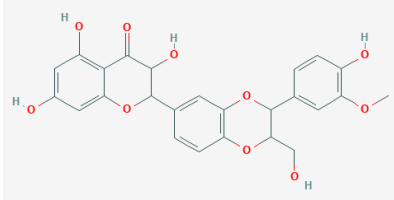

$\mathrm{HCV}$

$[168,169,212]$ 
Table 2. Cont.

\begin{tabular}{|c|c|c|c|c|}
\hline S. No & Name of the Compound & Structure & Antiviral Property against & Reference \\
\hline & 5. TANNINS & & & \\
\hline & $\begin{array}{l}\text { 5.1. Geraniin } \\
\text { (P. amarus) }\end{array}$ & & & \\
\hline 5. & $\begin{array}{c}\text { 5.2. 1,3,4,6-tetra-O-galloyl- } \\
\text { ß-d-glucose }(P . \\
\text { urinaria })\end{array}$ & & HSV and HIV & [172-175] \\
\hline & $\begin{array}{l}\text { 5.3. Corilagin } \\
\text { (P. amarus) }\end{array}$ & & & \\
\hline
\end{tabular}

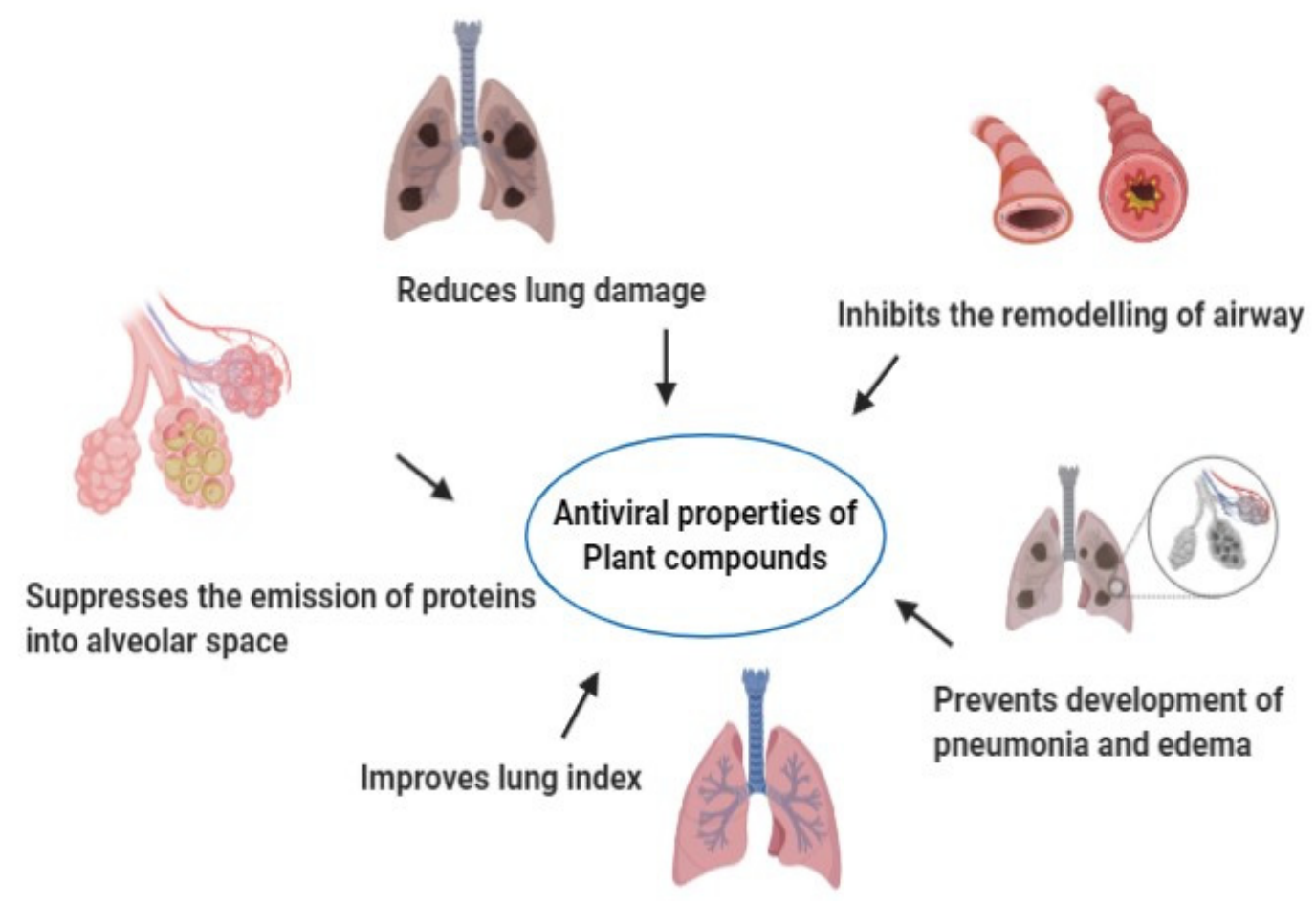

Figure 4. Antiviral properties of plant compounds. 
Table 3. Mechanism of antiviral action of phytochemical compounds and its derivatives.

\begin{tabular}{ll}
\hline S. No & Name of the Compound \\
\hline 1. & $\begin{array}{l}\text { Polysulphates (sulphated } \\
\text { polysaccharides) }\end{array}$
\end{tabular}
polysaccharides)

\section{Mechanism of Action}

- Shields the viral envelope gp120 that is essential for the viral attachment

- Decreases the viral attachment in MDCK cells

- $\quad$ EGCG inhibits the neuraminidase activity more efficiently than EGC

- $\quad$ EGCG binds to the envelope protein Gb, Gd or other

\section{EGCG and ECG}

envelope proteins of HSV-1 and HSV-2 that are essential for its fusion with the host cell membrane

- Catechin binds to the ACE2 and receptor binding domain of viral S-protein of SARS-CoV-2
$[95,97,201]$

\author{
(n)
}


Table 3. Cont.

\begin{tabular}{|c|c|c|c|}
\hline S. No & Name of the Compound & Mechanism of Action & Reference \\
\hline 7. & $\begin{array}{l}\text { Rhamnose residue containing } \\
\text { kaempferol }\end{array}$ & $\begin{array}{l}\text { - In HIV, it inhibits the reverse transcriptase enzyme } \\
\text { - } \quad \text { In H1N1 and H9N2, it affects the neuraminidase activity } \\
\text { - In Japanese encephalitis virus, it inhibits the RNA frame } \\
\text { - } \quad \text { Inhift } \\
\text { - Inhibits coronavirus release by effecting 3a channel } \\
\text { Inhits N3 binding site in the SARS-CoV-2 Mpro }\end{array}$ & {$[122,124-126]$} \\
\hline 8. & $\begin{array}{l}\text { Kaempferol } \\
\text { 3,7-bisrhamnoside }\end{array}$ & - $\quad$ Effective against HCV NS3 protease & [123] \\
\hline 9. & Triterpene saponin & $\begin{array}{l}\text { - It acts against the HSV-1 and poliovirus } 2 \text { by protecting the } \\
\text { host cells from cell damage and also by decreasing the viral } \\
\text { production }\end{array}$ & [131] \\
\hline
\end{tabular}

- In HSV it inhibits the viral capsid protein synthesis and also replication

10. Triterpenoid saponin TS21

11. Niranthin
- In HBV infection it inhibits the antigen expression

- In the case of duck HBV infection it inhibits the DNA replication
[134-136] effect, immunomodulatory and antiviral activities including SARS-CoV

- In the case of $\mathrm{HCV}$, it affects the viral proliferation by inhibiting the genome replication and viral assembly

- It suppresses the influenza A virus replication
[141-144]

$[139,140]$
12. Nordihydroguairetic acid

13. Terameprocol

- It inhibits the West Nile virus replication

[145-149]

- It inhibits the expression of P17 and P24 proteins of the HIV

14. Arctigenin

- In the case of HIV-1 and HSV, it protects the host by increasing the production of IFN

- In HeLa cells, it inhibits the HSV-1 virus DNA synthesis by inhibiting the expression of ICP0 and ICP4

$[155,156]$

- It inhibits the vacuolar ATPase in case of zika virus

- In the case of influenza A virus, it inhibits the infection by interfering with the downstream process

[157-161]
16. Diphyllin

15. Yatein

17. Patentiflorin A
- Prevents the fusion of the cell membrane of the host by inhibiting the acidification of endosomal and lysosomal cells [160-164]

- In HIV it inhibits the reverse transcriptase 
Table 3. Cont.

\begin{tabular}{lllll}
\hline S. No & Name of the Compound & & Mechanism of Action & Reference \\
\hline 18. & Clemastanin B & $\begin{array}{l}\text { In influenza A virus it affects the viral endocytosis and also } \\
\text { the ribonucleoprotein export }\end{array}$ & {$[164-167]$} \\
\hline 19. $\quad$ Silymarin C & - & $\begin{array}{l}\text { It inhibits the HCV production and also increases the } \\
\text { anti-inflamatory and antiproliferative gene expression } \\
\text { Lignins exhibits antiviral property by inhibition of viral } \\
\text { replication, protein and cytokine expression, and apoptosis } \\
\text { thus they may have effect on SARS-CoV-2 }\end{array}$ & {$[168-171]$} \\
\hline
\end{tabular}

\section{Conclusions}

This review presents detailed information about plants and herbs that are widely used to treat viral infections and their phytochemicals that possess antiviral properties. The mechanisms by which the phytochemicals act against the viruses are also elaborated in the review for better understanding. Future studies employing in vitro pharmacological tools to establish the structures of the compounds that inhibit SARS-CoV-2 infection will help in finding a cure for diseases that trigger fast-spreading pandemics. In-depth studies for in vitro and in vivo evaluation of these medicinal plants and their phytochemicals are warranted for assessing anti-SARS-CoV-2 activities. Exploiting the various modes of action of phytoconstituents would lead to practical utilization of the natural resources of plants and herbs for combating this pandemic virus effectively by designing and developing potent drugs and medicines.

Author Contributions: This review article was carried out in collaboration between the authors. Conceptualization, A.V.A., and K.D.; writing-original draft preparation, A.V.A., B.B.; selected bibliographic sources, M.K., M.A., K.B., A.P., N.S., S.V., M.S., M.V.A.; B.B. coordinated the working group; writing-review and editing, N.A.A.-D., M.I.Y., R.T., K.D. All authors have read and agreed to the published version of the manuscript.

Funding: This collection is a review manuscript written by the authors and required no substantial funding to be stated.

Acknowledgments: All the authors are thankful to their respective Universities and Institutes.

Conflicts of Interest: Authors do not have any conflict of interest.

Disclosure Statement: The authors have declared that there exist no financial relationships that could, in any way, lead to a potential conflict of interest.

\section{References}

1. Dhama, K.; Khan, S.; Tiwari, R.; Sircar, S.; Bhat, S.; Malik, Y.S.; Singh, K.P.; Chaicumpa, W.; Bonilla-Aldana, D.K.; RodriguezMorales, A.J. Coronavirus disease 2019-COVID-19. Clin. Microbiol. Rev. 2020, 33, e00028-20. [CrossRef]

2. Aanouz, I.; Belhassan, A.; El-Khatabi, K.; Lakhlifi, T.; El-Ldrissi, M.; Bouachrine, M. Moroccan Medicinal plants as inhibitors against SARS-CoV-2 main protease: Computational investigations. J. Biomol. Struct. Dyn. 2020, 1-9. [CrossRef] [PubMed]

3. Divya, M.; Vijayakumar, S.; Chen, J.; Vaseeharan, B.; Durán-Lara, E.F. A review of South Indian medicinal plant has the ability to combat against deadly viruses along with COVID-19? Microb. Pathog. 2020, 104277. [CrossRef] [PubMed]

4. Jahan, I.; Onay, A. Potentials of plant-based substance to inhabit and probable cure for the COVID-19. Turk. J. Biol 2020, 44, 228-241. [CrossRef] [PubMed]

5. Ul Qamar, M.T.; Alqahtani, S.M.; Alamri, M.A.; Chen, L.L. Structural basis of SARS-CoV-2 3CL pro and anti-COVID-19 drug discovery from medicinal plants. J. Pharm. Anal. 2020, 10, 313-319. [CrossRef]

6. Xu, J.; Zhang, Y. Traditional Chinese medicine treatment of COVID-19. Complement. Clin. Pr. 2020, 39, 101165. [CrossRef]

7. Devanssh, M. Possible plant based medicines and phytochemicals to be cure for deadly coronavirus COVID 19. World J. Pharm. Pharm. Sci. 2020, 9, 531-533. [CrossRef]

8. Mani, J.S.; Johnson, J.B.; Steel, J.C.; Broszczak, D.A.; Neilsen, P.M.; Walsh, K.B.; Naiker, M. Natural product-derived phytochemicals as potential agents against coronaviruses: A review. Virus Res. 2020, 284, 197989. [CrossRef] 
9. Joshi, T.; Joshi, T.; Sharma, P.; Mathpal, S.; Pundir, H.; Bhatt, V.; Chandra, S. In silico screening of natural compounds against COVID-19 by targeting $\mathrm{M}^{\text {pro }}$ and ACE2 using molecular docking. Eur. Rev. Med. Pharm. Sci. 2020, 24, 4529-4536. [CrossRef]

10. Guo, Y.R.; Cao, Q.D.; Hong, Z.S.; Tan, Y.Y.; Chen, S.D.; Jin, H.J.; Tan, K.S.; Wang, D.Y.; Yan, Y. The origin, transmission and clinical therapies on coronavirus disease 2019 (COVID-19) outbreak-an update on the status. Mil. Med Res. 2020, 7, 1-10. [CrossRef]

11. Ganjhu, R.K.; Mudgal, P.P.; Maity, H.; Dowarha, D.; Devadiga, S.; Nag, S.; Arunkumar, G. Herbal plants and plant preparations as remedial approach for viral diseases. Virusdisease 2015, 26, 225-236. [CrossRef]

12. Tiwari, R.; Latheef, S.K.; Ahmed, I.; Iqbal, H.; Bule, M.H.; Dhama, K.; Samad, H.A.; Karthik, K.; Alagawany, M.; El-Hack, M.E.; et al. Herbal immunomodulators-A remedial panacea for designing and developing effective drugs and medicines: Current scenario and future prospects. Curr. Drug Metab. 2018, 19, 264-301. [CrossRef]

13. Dhama, K.; Karthik, K.; Khandia, R.; Munjal, A.; Tiwari, R.; Rana, R.; Khurana, S.K.; Ullah, S.; Khan, R.U.; Alagawany, M.; et al. Medicinal and therapeutic potential of herbs and plant metabolites / extracts countering viral pathogens-Current knowledge and future prospects. Curr. Drug Metab. 2018, 19, 236-263. [CrossRef]

14. Mousavizadeh, L.; Ghasemi, S. Genotype and phenotype of COVID-19: Their roles in pathogenesis. J. Microbiol. Immunol. Infect. 2020, S1684-1182(20)30082-7. [CrossRef] [PubMed]

15. De Haan, C.A.; Kuo, L.; Masters, P.S.; Vennema, H.; Rottier, P.J. Coronavirus particle assembly: Primary structure requirements of the membrane protein. J. Virol. 1998, 72, 6838-6850. [CrossRef]

16. van Boheemen, S.; de Graaf, M.; Lauber, C.; Bestebroer, T.M.; Raj, V.S.; Zaki, A.M.; Osterhaus, A.D.; Haagmans, B.L.; Gorbalenya, A.E.; Snijder, E.J.; et al. Genomic characterization of a newly discovered coronavirus associated with acute respiratory distress syndrome in humans. mBio 2012, 3, e00473-12. [CrossRef] [PubMed]

17. Czub, M.; Weingartl, H.; Czub, S.; He, R.; Cao, J. Evaluation of modified vaccinia virus Ankara based recombinant SARS vaccine in ferrets. Vaccine 2005, 23, 2273-2279. [CrossRef] [PubMed]

18. Hoffmann, M.; Kleine-Weber, H.; Schroeder, S.; Krüger, N.; Herrler, T.; Erichsen, S.; Schiergens, T.S.; Herrler, G.; Wu, N.H.; Nitsche, A.; et al. SARS-CoV-2 cell entry depends on ACE2 and TMPRSS2 and is blocked by a clinically proven protease inhibitor. Cell 2020, 181, 271-280.e8. [CrossRef] [PubMed]

19. South, A.M.; Brady, T.M.; Flynn, J.T. ACE2 (Angiotensin-Converting Enzyme 2), COVID-19, and ACE Inhibitor and Ang II (Angiotensin II) receptor blocker use during the pandemic: The pediatric perspective. Hypertension 2020, 76, 16-22. [CrossRef] [PubMed]

20. Sola, I.; Almazan, F.; Zuniga, S.; Enjuanes, L. Continuous and discontinuous RNA synthesis in coronaviruses. Annu. Rev. Virol. 2015, 2, 265-288. [CrossRef] [PubMed]

21. Ziebuhr, J. Coronavirus replication and reverse genetics. In Current Topics in Microbiology and Immunology; Enjuanes, L., Ed.; Springer: Berlin/Heidelberg, Germany, 2005; Volume 287, pp. 57-94. [CrossRef]

22. Šebera, J.; Dubankova, A.; Sychrovský, V.; Ruzek, D.; Boura, E.; Nencka, R. The structural model of Zika virus RNA-dependent RNA polymerase in complex with RNA for rational design of novel nucleotide inhibitors. Sci. Rep. 2018, 8, 11132. [CrossRef]

23. Rupprecht, C.E. Rhabdovirus. In Medical Microbiology, 4th ed.; University of Texas Medical Branch at Galveston: Galveston, TX, USA, 1996.

24. Kuhn, R.J.; Zhang, W.; Rossmann, M.G.; Pletnev, S.V.; Corver, J.; Lenches, E.; Jones, C.T.; Mukhopadhyay, S.; Chipman, P.R.; Strauss, E.G.; et al. Structure of dengue virus: Implications for flavivirus organization, maturation, and fusion. Cell 2002, 108, 717-725. [CrossRef]

25. Jilani, T.N.; Jamil, R.T.; Siddiqui, A.H. H1N1 influenza (swine flu). In StatPearls; Stat Pearls Publishing: Treasure Island, FL, USA, 2019.

26. Ganesan, V.K.; Duan, B.; Reid, S.P. Chikungunya virus: Pathophysiology, mechanism, and modeling. Viruses 2017, 9 , 368 [CrossRef]

27. Lee, J.E.; Saphire, E.O. Ebolavirus glycoprotein structure and mechanism of entry. Future Virol. 2009, 4, 621-635. [CrossRef] [PubMed]

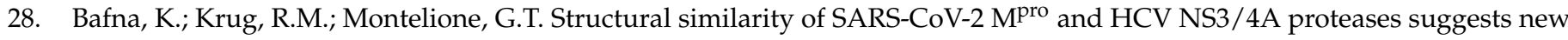
approaches for identifying existing drugs useful as COVID-19 therapeutics. ChemRxiv 2020. [CrossRef]

29. Biswas, A.; Bhattacharjee, U.; Chakrabarti, A.K.; Tewari, D.N.; Banu, H.; Dutta, S. Emergence of novel coronavirus and COVID-19: Whether to stay or die out? Crit. Rev. Microbiol. 2020, 46, 182-193. [CrossRef] [PubMed]

30. Fanales-Belasio, E.; Raimondo, M.; Suligoi, B.; Buttò, S. HIV virology and pathogenetic mechanisms of infection: A brief overview. Ann. Sanita 2010, 46, 5-14. [CrossRef]

31. Gupta, H.M.; Gupta, S.; Bhargava, S. Potential use of Turmeric in COVID-19. Clin. Exp. Derm. 2020. [CrossRef]

32. Li, Y.; Liu, X.; Guo, L.; Li, J.; Zhong, D.; Zhang, Y.; Clarke, M.; Jin, R. Traditional Chinese herbal medicine for treating novel coronavirus (COVID-19) pneumonia: Protocol for a systematic review and meta-analysis. Syst. Rev. 2020, 9, 75. [CrossRef]

33. Junhai, J. Inventor Herbal Medicine for Treating and Preventing Rabies, Herbal Medicine for Treating and Preventing Rabies. Patent No. CN 200510032451, 23 November 2005.

34. Bliah, M.A.M. Google Patents. Antiviral Composition. Patent No. EP19850109500, 19 August 1987.

35. Chandan, B.K.; Sharma, A.K.; Anand, K.K. Boerhaavia diffusa: A study of its hepatoprotective activity. J. Ethnopharmacol. 1991, 31, 299-307. [CrossRef] 
36. Verma, H.N.; Awasthi, L.P. Occurrence of a highly antiviral agent in plants treated with Boerhaavia diffusa inhibitor. Can. J. Bot. 1980, 58, 2141-2144. [CrossRef]

37. Dalal, S.; Kataria, S.K.; Sastry, K.V.; Rana, S.V. Phytochemical screening of methanolic extract and antibacterial activity of active principles of hepatoprotective herb, Eclipta alba. Ethnobot. Leafl. 2010, 2010, 3. Available online: https://opensiuc.lib.siu.edu/ebl/ vol2010/iss3/3 (accessed on 21 July 2020).

38. Anbazhagan, G.K.; Palaniyandi, S.; Joseph, B. Antiviral Plant Extracts. In Plant Extracts; Intech Open Dekebo, A: London, UK, 2019. [CrossRef]

39. Razdan, R.; Dev, M.A. Preventive and curative effects of Vedic Guard against antitubercular drugs induced hepatic damage in rats. Pharmacogn. Mag. 2008, 4, 182-188.

40. Mukherjee, P.K. Antiviral evaluation of herbal drugs. Qual. Control. Eval. Herb. Drugs 2019, 599-628. [CrossRef]

41. McGill, M.R.; Du, K.; Weemhoff, J.L.; Jaeschke, H. Critical review of resveratrol in xenobiotic-induced hepatotoxicity. Food Chem. Toxicol. 2015, 86, 309-318. [CrossRef] [PubMed]

42. Cortegiani, A.; Ingoglia, G.; Ippolito, M.; Giarratano, A.; Einav, S. A systematic review on the efficacy and safety of chloroquine for the treatment of COVID-19. J. Crit. Care 2020, 57, 279-283. [CrossRef]

43. Li, X.; Wang, Y.; Agostinis, P.; Rabson, A.; Melino, G.; Carafoli, E.; Shi, Y.; Sun, E. Is hydroxychloroquine beneficial for COVID-19 patients? Cell Death Dis. 2020, 11, 1-6.

44. Singh, A.K.; Singh, A.; Shaikh, A.; Singh, R.; Misra, A. Chloroquine and hydroxychloroquine in the treatment of COVID-19 with or without diabetes: A systematic search and a narrative review with a special reference to India and other developing countries. Diabetes Metab. Syndr. 2020, 14, 241-246. [CrossRef] [PubMed]

45. Salehi, B.; Shivaprasad Shetty, M.; V Anil Kumar, N.; Živković, J.; Calina, D.; Oana Docea, A.; Emamzadeh-Yazdi, S.; Sibel Kılıç, C.; Goloshvili, T.; Nicola, S.; et al. Veronica plants-drifting from farm to traditional healing, food application, and phytopharmacology. Molecules 2019, 24, 2454. [CrossRef] [PubMed]

46. Malik, K.; Ahmad, M.; Zafar, M.; Ullah, R.; Mahmood, H.M.; Parveen, B.; Rashid, N.; Sultana, S.; Shah, S.N. An ethnobotanical study of medicinal plants used to treat skin diseases in northern Pakistan. BMC Complementary Altern. Med. 2019, 19, 210. [CrossRef] [PubMed]

47. Chattopadhyay, D.; Ojha, D.; Mondal, S.; Goswami, D. Validation of antiviral potential of herbal ethnomedicine. In Evidence-Based Validation of Herbal Medicine; Mukherjee, P.K., Ed.; Elsevier: Amsterdam, The Netherlands, 2015; pp. 175-200. [CrossRef]

48. Chandra, S.; Rawat, D.S. Medicinal plants of the family Caryophyllaceae: A review of ethno-medicinal uses and pharmacological properties. Integr. Med. Res. 2015, 4, 123-131. [CrossRef] [PubMed]

49. Umesh, K.D.; Selvaraj, C.; Singh, S.K.; Dubey, V.K. Identification of new anti-nCoV drug chemical compounds from Indian spices exploiting SARS-CoV-2 main protease as target. J. Biomol. Struct. Dyn. 2020, 1-9. [CrossRef] [PubMed]

50. Sarma, P.; Shekhar, N.; Prajapat, M. In-silico homology assisted identification of inhibitor of RNA binding against 2019-nCoV N-protein (N terminal domain). J. Biomol. Struct. Dyn 2020, 1-9. [CrossRef]

51. Gupta, M.K.; Vemula, S.; Donde, R.; Gouda, G.; Behera, L.; Vadde, R. In-silico approaches to detect inhibitors of the human severe acute respiratory syndrome coronavirus envelope protein ion channel. J. Biomol. Struct. Dyn. 2020, 1-11. [CrossRef]

52. Sinha, S.K.; Prasad, S.K.; Islam, M.A.; Gurav, S.S.; Patil, R.B.; AlFaris, N.A.; Aldayel, T.S.; AlKehayez, N.M.; Wabaidur, S.M.; Shakya, A. Identification of bioactive compounds from Glycyrrhiza glabra as possible inhibitor of SARS-CoV-2 spike glycoprotein and non-structural protein-15: A pharmacoinformatics study. J. Biomol. Struct. Dyn. 2020, 1-15. [CrossRef] [PubMed]

53. Fiore, C.; Eisenhut, M.; Krausse, R.; Ragazzi, E.; Pellati, D.; Armanini, D.; Bielenberg, J. Antiviral effects of Glycyrrhiza species. Phytother. Res. Int. J. Devoted Pharmacol. Toxicol. Eval. Nat. Prod. Deriv. 2008, 22, 141-148. [CrossRef]

54. Michaelis, M.; Geiler, J.; Naczk, P.; Sithisarn, P.; Leutz, A.; Doerr, H.W.; Cinatl, J., Jr. Glycyrrhizin exerts antioxidative effects in $\mathrm{H} 5 \mathrm{~N} 1$ influenza A virus-infected cells and inhibits virus replication and pro-inflammatory gene expression. PLoS ONE 2011, 6, e19705. [CrossRef]

55. Murck, H. Symptomatic Protective action of glycyrrhizin (licorice) in COVID-19 Infection? Front. Immunol. 2020, 11, 1239. [CrossRef]

56. LuoLiu, P.; Li, J. Pharmacologic perspective: Glycyrrhizin may be an efficacious therapeutic agent for COVID-19. Int J. Antimicrob. Agents 2020, 105995. [CrossRef]

57. Bailly, C.; Vergoten, G. Glycyrrhizin: An alternative drug for the treatment of COVID-19 infection and the associated respiratory syndrome? Pharmacol. Ther. 2020, 214, 107618. [CrossRef]

58. Subramanian, S. Some FDA Approved drugs exhibit binding affinity as high as- $16.0 \mathrm{kcal} / \mathrm{mol}$ against COVID-19 Main Protease (Mro): A molecular docking study. IndiaRxiv 2020, 1-6. [CrossRef]

59. Joshi, G.; Sharma, S.; Acharya, J.; Parida, M. Assessment of In vitro antiviral activity of Ocimum sanctum (Tulsi) against pandemic swine flu H1N1 virus infection. World Res. J. Antimicrob. Agents 2014, 3, 062-067.

60. Mohapatra, P.K.; Chopdar, K.S.; Dash, G.C.; Raval, M.K. In silico screening of phytochemicals of Ocimum sanctum against main protease of SARS-CoV-2. ChemRxiv 2020. [CrossRef]

61. Purthvish, R.; Gopinatha, S.M. Antiviral prospective of Tinospora cordifolia on HSV-1. Int. J. Curr. Microbiol. App. Sci 2018, 7, 3617-3624. [CrossRef] 
62. Krupanidhi, S.; Abraham, P.K.; Venkateswarulu, T.C.; Ayyagari, V.S.; Nazneen Bobby, M.; John Babu, D.; Venkata Narayana, A.; Aishwarya, G. Screening of phytochemical compounds of Tinospora cordifolia for their inhibitory activity on SARS-CoV-2: An in silico study. J. Biomol. Struct. Dyn. 2020, 1-5. [CrossRef]

63. Donma, M.M.; Donma, O. The effects of Allium sativum on immunity within the scope of COVID-19 infection. Med. Hypotheses 2020, 144, 109934. [CrossRef] [PubMed]

64. Thuy, B.T.P.; My, T.T.A.; Hai, N.T.T.; Hieu, L.T.; Hoa, T.T.; Thi Phuong Loan, H.; Triet, N.T.; Anh, T.T.V.; Quy, P.T.; Tat, P.V.; et al. Investigation into SARS-CoV-2 resistance of compounds in garlic essential oil. ACS Omega 2020, 5, 8312-8320. [CrossRef]

65. Wintachai, P.; Kaur, P.; Lee, R.C.; Ramphan, S.; Kuadkitkan, A.; Wikan, N.; Ubol, S.; Roytrakul, S.; Chu, J.J.; Smith, D.R. Activity of andrographolide against chikungunya virus infection. Sci. Rep. 2015, 5, 14179. [CrossRef] [PubMed]

66. Murugan, N.A.; Pandian, C.J.; Jeyakanthan, J. Computational investigation on Andrographis paniculata phytochemicals to evaluate their potency against SARS-CoV-2 in comparison to known antiviral compounds in drug trials. J. Biomol. Struct. Dyn. 2020, 1-12. [CrossRef]

67. Enmozhi, S.K.; Raja, K.; Sebastine, I.; Joseph, J. Andrographolide as a potential inhibitor of SARS-CoV-2 main protease: An in silico approach. J. Biomol. Struct. Dyn. 2020, 1-7. [CrossRef] [PubMed]

68. John, J. Therapeutic potential of Withania somnifera: A report on phyto-pharmacological properties. Int J. Pharm Sci Res 2014, 5, 2131-2148. [CrossRef]

69. Kaur, N.; Junaid, N.; Raman, B. A review on pharmacological profile of Withania somnifera (Ashwagandha). Res. Rev. J. Bot. Sci. 2013, 2, 6-14.

70. Saiyed, A.; Jahan, N.; Majeedi, S.F.; Roqaiya, M. Medicinal properties, phytochemistry and pharmacology of Withania somnifera: An important drug of Unani medicine. J. Sci. Innov. Res. 2016, 5, 156-160.

71. Grover, A.; Agrawal, V.; Shandilya, A.; Bisaria, V.S.; Sundar, D. Non-nucleosidic inhibition of Herpes simplex virus DNA polymerase: Mechanistic insights into the anti-herpetic mode of action of herbal drug withaferin A. BMC Bioinform. 2011, 12, 1-9. [CrossRef] [PubMed]

72. Tripathi, M.K.; Singh, P.; Sharma, S.; Singh, T.P.; Ethayathulla, A.S.; Kaur, P. Identification of bioactive molecule from Withania somnifera (Ashwagandha) as SARS-CoV-2 main protease inhibitor. J. Biomol. Struct. Dyn. 2020, 1-14. [CrossRef]

73. Chikhale, R.V.; Gurav, S.S.; Patil, R.B.; Sinha, S.K.; Prasad, S.K.; Shakya, A.; Shrivastava, S.K.; Gurav, N.S.; Prasad, R.S. Sars-cov-2 host entry and replication inhibitors from Indian ginseng: An in-silico approach. J. Biomol. Struct. Dyn. 2020, 1-12. [CrossRef]

74. Ichsyani, M.; Ridhanya, A.; Risanti, M.; Desti, H.; Ceria, R.; Putri, D.H.; Sudiro, T.M.; Dewi, B.E. Antiviral effects of Curcuma longa L. against dengue virus in vitro and in vivo. Iniop. Conf. Ser. Earth Environ. Sci. 2017, 101, 012005. [CrossRef]

75. Zandi, K.; Ramedani, E.; Mohammadi, K.; Tajbakhsh, S.; Deilami, I.; Rastian, Z.; Fouladvand, M.; Yousefi, F.; Farshadpour, F. Evaluation of antiviral activities of curcumin derivatives against HSV-1 in Vero cell line. Nat. Prod. Commun. 2010, 5, $1935-1938$. [CrossRef]

76. Gupta, S.; Singh, A.K.; Kushwaha, P.P.; Prajapati, K.S.; Shuaib, M.; Senapati, S.; Kumar, S. Identification of potential natural inhibitors of SARS-CoV2 main protease by molecular docking and simulation studies. J. Biomol. Struct. Dyn. 2020, 1-12. [CrossRef] [PubMed]

77. Ghosh, R.; Chakraborty, A.; Biswas, A.; Chowdhuri, S. Evaluation of green tea polyphenols as novel corona virus (SARS CoV-2) main protease (Mpro) inhibitors-An in silico docking and molecular dynamics simulation study. J. Biomol. Struct. Dyn. 2020, 1-13. [CrossRef] [PubMed]

78. Hamza, M.; Ali, A.; Khan, S.; Ahmed, S.; Attique, Z.; Ur Rehman, S.; Khan, A.; Ali, H.; Rizwan, M.; Munir, A.; et al. nCOV-19 peptides mass fingerprinting identification, binding, and blocking of inhibitors flavonoids and anthraquinone of Moringa oleifera and hydroxychloroquine. J. Biomol. Struct. Dyn. 2020, 1-11. [CrossRef]

79. Tan, W.; Jaganath, I.; Manikam, I. Evaluation of antiviral activities of four local Malaysian Phyllanthus species against Herpes simplex viruses and possible antiviral target. Int. J. Med Sci. 2013, 10, 1817-1892. [CrossRef] [PubMed]

80. Alzohairy, A.M. Therapeutics role of Azadirachta indica (Neem) and their active constituents in diseases prevention and treatment. Evid. Based Complementary Altern. Med. 2016, 7382506. [CrossRef]

81. Rao, V.B.; Yeturu, K. Possible Anti-viral effects of Neem (Azadirachta indica) on dengue virus. bioRxiv 2020. [CrossRef]

82. Fesseha, H.; Goa, E. Therapeutic value of garlic (Allium sativum): A review. Adv. Food Technol Nutr Sci Open J 2019, 5, 107-117. [CrossRef]

83. Singh, S.S.; Pandey, S.C.; Srivastava, S.; Gupta, V.S.; Patro, B.; Ghosh, A.C. Chemistry and medicinal properties of Tinospora cordifolia (Guduchi). Indian J. Pharmacol. 2003, 35, 83-91.

84. Paikra, B.K.; Dhongade, H.K.J.; Gidwani, B. Phytochemistry and pharmacology of Moringa oleifera Lam. J. Pharm. 2017, 20, 194-200. [CrossRef]

85. Karmakar, P.; Pujol, C.A.; Damonte, E.B.; Ghosh, T.; Ray, B. Polysaccharides from Padina tetrastromatica: Structural features, chemical modification and antiviral activity. Carbohydr. Polym. 2010, 80, 513-520. [CrossRef]

86. Herold, B.C.; Gerber, S.I.; Polonsky, T.; Belval, B.J.; Shaklee, P.N.; Holme, K. Identification of structural features of heparin required for inhibition of herpes simplex virus type 1 binding. Virology 1995, 206, 1108-1116. [CrossRef]

87. Huheihel, M.; Ishanu, V.; Tal, J. Activity of Porphyridium sp. polysaccharide against herpes simplex viruses in vitro and in vivo. J. Biochem. Biophys. Methods 2002, 50, 189-200. [CrossRef] 
88. Ogbole, O.O.; Akinleye, T.E.; Segun, P.A.; Faleye, T.C.; Adeniji, A.J. In vitro antiviral activity of twenty-seven medicinal plant extracts from Southwest Nigeria against three serotypes of echoviruses. Virol. J. 2018, 15, 110. [CrossRef]

89. Andres, A.; Donovan, S.M.; Kuhlenschmidt, M.S. Soy isoflavones and virus infections. J. Nutr. Biochem. 2009, 20, 563-569. [CrossRef]

90. Liu, A.L.; Liu, B.; Qin, H.L.; Lee, S.M.; Wang, Y.T.; Du, G.H. Anti-influenza virus activities of flavonoids from the medicinal plant Elsholtzia rugulosa. Planta Med. 2008, 74, 847-851. [CrossRef] [PubMed]

91. Ngwa, W.; Kumar, R.; Thompson, D.; Lyerly, W.; Moore, R.; Reid, T.E.; Lowe, H.; Toyang, N. Potential of flavonoid-inspired phytomedicines against COVID-19. Molecules 2020, 25, 2707. [CrossRef]

92. Bhowmik, D.; Nandi, R.; Kumar, D. Evaluation of flavonoids as 2019-nCoV cell entry inhibitor through molecular docking and pharmacological analysis. ChemRxiv 2020. [CrossRef]

93. Colunga Biancatelli, R.M.L.; Berrill, M.; Catravas, J.D.; Marik, P.E. Quercetin and vitamin C: An experimental, synergistic therapy for the prevention and treatment of SARS-CoV-2 related disease (COVID-19). Front. Immunol. 2020, 11, 1451. [CrossRef] [PubMed]

94. Saeed, M.; Naveed, M.; Arif, M.; Kakar, M.U.; Manzoor, R.; Abd El-Hack, M.E.; Alagawany, M.; Tiwari, R.; Khandia, R.; Munjal, A.; et al. Green tea (Camellia sinensis) and l-theanine: Medicinal values and beneficial applications in humans-A comprehensive review. Biomed. Pharm. 2017, 95, 1260-1275. [CrossRef]

95. Song, J.M.; Lee, K.H.; Seong, B.L. Antiviral effect of catechins in green tea on influenza virus. Antivir. Res. 2005, 68, 66-74. [CrossRef] [PubMed]

96. Isaacs, C.E.; Wen, G.Y.; Xu, W.; Jia, J.H.; Rohan, L.; Corbo, C.; Di Maggio, V.; Jenkins, E.C.; Hillier, S. Epigallocatechin gallate inactivates clinical isolates of herpes simplex virus. Antimicrob. Agents Chemother. 2008, 52, 962-970. [CrossRef]

97. Jena, A.B.; Kanungo, N.; Nayak, V.; Chainy, G.B.N.; Dandapat, J. Catechin and curcumin interact with corona (2019-nCoV/SARSCoV2) viral S protein and ACE2 of human cell membrane: Insights from computational study and implication for intervention. Nature 2020. [CrossRef]

98. Harwood, M.; Danielewska-Nikiel, B.; Borzelleca, J.F.; Flamm, G.W.; Williams, G.M.; Lines, T.C. A critical review of the data related to the safety of quercetin and lack of evidence of in vivo toxicity, including lack of genotoxic/carcinogenic properties. Food Chem. Toxicol. 2007, 45, 2179-2205. [CrossRef] [PubMed]

99. Gonzalez, O.; Fontanes, V.; Raychaudhuri, S.; Loo, R.; Loo, J.; Arumugaswami, V.; Sun, R.; Dasgupta, A.; French, S.W. The heat shock protein inhibitor Quercetin attenuates hepatitis C virus production. Hepatology 2009, 50, 1756-1764. [CrossRef]

100. Bachmetov, L.; Gal-Tanamy, M.; Shapira, A.; Vorobeychik, M.; Giterman-Galam, T.; Sathiyamoorthy, P.; Golan-Goldhirsh, A.; Benhar, I.; Tur-Kaspa, R.; Zemel, R. Suppression of hepatitis C virus by the flavonoid quercetin is mediated by inhibition of NS3 protease activity. J. Viral Hepat. 2012, 19, e81-e88. [CrossRef]

101. Ganesan, S.; Faris, A.N.; Comstock, A.T.; Wang, Q.; Nanua, S.; Hershenson, M.B.; Sajjan, U.S. Quercetin inhibits rhinovirus replication in vitro and in vivo. Antivir. Res. 2012, 94, 258-271. [CrossRef]

102. Zandi, K.; Teoh, B.T.; Sam, S.S.; Wong, P.F.; Mustafa, M.R.; Abu Bakar, S. Antiviral activity of four types of bioflavonoid against dengue virus type-2. Virol. J. 2011, 8, 1. [CrossRef] [PubMed]

103. Hakobyan, A.; Arabyan, E.; Avetisyan, A.; Abroyan, L.; Hakobyan, L.; Zakaryan, H. Apigenin inhibits African swine fever virus infection in vitro. Arch. Virol. 2016, 161, 3445-3453. [CrossRef] [PubMed]

104. Lv, X.; Qiu, M.; Chen, D.; Zheng, N.; Jin, Y.; Wu, Z. Apigenin inhibits enterovirus 71 replication through suppressing viral IRES activity and modulating cellular JNK pathway. Antivir. Res. 2014, 109, 30-41. [CrossRef] [PubMed]

105. Rogerio, A.P.; Dora, C.L.; Andrade, E.L.; Chaves, J.S.; Silva, L.F.; Lemos-Senna, E.; Calixto, J.B. Anti-inflammatory effect of quercetin-loaded microemulsion in the airways allergic inflammatory model in mice. Pharmacol. Res. 2010, 1, 288-297. [CrossRef]

106. Zhang, W.; Qiao, H.; Lv, Y.; Wang, J.; Chen, X.; Hou, Y.; Tan, R.; Li, E. Apigenin inhibits enterovirus-71 infection by disrupting viral RNA association with trans-acting factors. PLoS ONE 2014, 9, e110429. [CrossRef] [PubMed]

107. Shibata, C.; Ohno, M.; Otsuka, M.; Kishikawa, T.; Goto, K.; Muroyama, R.; Kato, N.; Yoshikawa, T.; Takata, A.; Koike, K. The flavonoid apigenin inhibits hepatitis C virus replication by decreasing mature microRNA122 levels. Virology 2014, 462, 42-48. [CrossRef]

108. Huang, H.; Zhou, W.; Zhu, H.; Zhou, P.; Shi, X. Baicalin benefits the anti-HBV therapy via inhibiting HBV viral RNAs. Toxicol. Appl. Pharm. 2017, 323, 36-43. [CrossRef]

109. Sithisarn, P.; Michaelis, M.; Schubert-Zsilavecz, M.; Cinatl Jr, J. Differential antiviral and anti-inflammatory mechanisms of the flavonoids biochanin A and baicalein in H5N1 influenza A virus-infected cells. Antivir. Res. 2013, 97, 41-48. [CrossRef]

110. Xu, G.; Dou, J.; Zhang, L.; Guo, Q.; Zhou, C. Inhibitory effects of baicalein on the influenza virus in vivo is determined by baicalin in the serum. Biol. Pharm. Bull. 2010, 33, 238-243. [CrossRef]

111. Dou, J.; Chen, L.; Xu, G.; Zhang, L.; Zhou, H.; Wang, H.; Su, Z.; Ke, M.; Guo, Q.; Zhou, C. Effects of baicalein on Sendai virus in vivo are linked to serum baicalin and its inhibition of hemagglutinin-neuraminidase. Arch. Virol. 2011, 156, 793-801. [CrossRef] [PubMed]

112. Chu, M.; Xu, L.; Zhang, M.B.; Chu, Z.Y.; Wang, Y.D. Role of Baicalin in anti-influenza virusA as a potent inducer of IFN gamma. Biomed. Res. Int. 2015, 2015, 263630. [CrossRef] [PubMed]

113. Fan, W.; Qian, S.; Qian, P.; Li, X. Antiviral activity of luteolin against Japanese encephalitis virus. Virus Res. 2016, 220, 112-116. [CrossRef] [PubMed] 
114. Knipping, K.; Garssen, J.; van't, L.B. An evaluation of the inhibitory effects against rotavirus infection of edible plant extracts. Virol. J. 2012, 9, 1-8. [CrossRef] [PubMed]

115. Murali, K.S.; Sivasubramanian, S.; Vincent, S.; Murugan, S.B.; Giridaran, B.; Dinesh, S.; Gunasekaran, P.; Krishnasamy, K.; Sathishkumar, R. Anti-chikungunya activity of luteolin and apigenin rich fraction from Cynodon dactylon. Asian Pac. J. Trop. Med. 2015, 8, 352-358. [CrossRef]

116. Yi, L.; Li, Z.; Yuan, K.; Qu, X.; Chen, J.; Wang, G.; Zhang, H.; Luo, H.; Zhu, L.; Jiang, P.; et al. Small molecules blocking the entry of severe acute respiratory syndrome coronavirus into host cells. J. Virol. 2004, 78, 11334-11339. [CrossRef]

117. Mehla, R.; Bivalkar-Mehla, S.; Chauhan, A. Aflavonoid, luteolin, cripples HIV-1 by abrogation of tat function. PLoS ONE 2011, 6, e27915. [CrossRef]

118. Wu, H.; Myszka, D.G.; Tendian, S.W.; Brouillette, C.G.; Sweet, R.W.; Chaiken, I.M.; Hendrickson, W.A. Kinetic and structural analysis of mutant CD4 receptors that are defective in HIV gp120 binding. Proc. Natl. Acad. Sci. USA 1996, 93, 15030-15035. [CrossRef]

119. Xu, L.; Su, W.; Jin, J.; Chen, J.; Li, X.; Zhang, X.; Sun, M.; Sun, S.; Fan, P.; An, D.; et al. Identification of luteolin as enterovirus 71 and coxsackievirus A16 inhibitors through reporter viruses and cell viability-based screening. Viruses 2014, 6, $2778-2795$. [CrossRef]

120. Ansari, W.A.; Ahamad, T.; Khan, M.A.; Khan, Z.A.; Khan, M.F. Luteolin: A dietary molecule as potential anti-COVID-19 agent. Comput. Chem. 2020. [CrossRef]

121. Mitrocotsa, D.; Mitaku, S.; Axarlis, S.; Harvala, C.; Malamas, M. Evaluation of the antiviral activity of kaempferol and its glycosides against human cytomegalovirus. Planta Med. 2000, 66, 377-379. [CrossRef]

122. Schwarz, S.; Sauter, D.; Wang, K.; Zhang, R.; Sun, B.; Karioti, A.; Bilia, A.R.; Efferth, T.; Schwarz, W. Kaempferol derivatives as antiviral drugs against the 3 a channel protein of coronavirus. Planta Med. 2014, 80, 177-182. [CrossRef]

123. Yang, L.; Lin, J.; Zhou, B.; Liu, Y.; Zhu, B. Activity of compounds from Taxillus sutchuenensis as inhibitors of HCV NS3serine protease. Nat. Prod. Res. 2016, 13, 1-5. [CrossRef]

124. Jeong, H.J.; Ryu, Y.B.; Park, S.; Kim, J.H.; Kwon, H.-J.; Kim, J.H.; Park, K.H.; Rho, M.-C.; Lee, W.S. Neuraminidase inhibitory activities of flavonols isolated from Rhodiola rosea roots and their in vitro anti-influenza viral activities. Bioorg. Med. Chem. 2009, 17, 6816-6823. [CrossRef] [PubMed]

125. Zhang, T.; Wu, Z.; Du, J.; Hu, Y.; Liu, L.; Yang, F.; Jin, Q. Anti-Japanese-encephalitis-viral effects of kaempferol and daidzin and their RNA-binding characteristics. PLoS ONE 2012, 7, e30259. [CrossRef]

126. Owis, A.I.; El-Hawary, M.S.; Dalia, E.L.; Amir Omar, M.A.; Abdelmohsen, U.R.; Kamel, M.S. Molecular docking reveals the potential of Salvadora persica flavonoids to inhibit COVID-19 virus main protease. RSC Adv. 1957, 10, 19570-19575. [CrossRef]

127. Ieven, M.; Vlietinick, A.J.; Berghe, D.V.; Totte, J.; Dommisse, R.; Esmans, E.; Alderweireldt, F. Plant antiviral agents. III. Isolation of alkaloids from Clivia miniata Regel (Amaryl-lidaceae). J. Nat. Prod. 1982, 45, 564-573. [CrossRef] [PubMed]

128. Li, S.Y.; Chen, C.; Zhang, H.Q.; Guo, H.Y.; Wang, H.; Wang, L.; Zhang, X.; Hua, S.N.; Yu, J.; Xiao, P.G.; et al. Identification of natural compounds with antiviral activities against SARS-associated coronavirus. Antivir. Res. 2005, 67, 18-23. [CrossRef] [PubMed]

129. Flamand, L.; Lautenschlager, I.; Krueger, G.; Ablashi, D. (Eds.) Human Herpesviruses HHV-6A, HHV-6B and HHV-7: Diagnosis and Clinical Management; Elsevier: Amsterdam, The Netherlands, 2014.

130. Ren, G.; Ding, G.; Zhang, H.; Wang, H.; Jin, Z.; Yang, G.; Han, Y.; Zhang, X.; Li, G.; Li, W. Antiviral activity of sophoridine against enterovirus 71 in vitro. J. Ethnopharmacol. 2019, 236, 124-128. [CrossRef]

131. Zhang, Y.; Zhu, H.; Ye, G.; Huang, C.; Yang, Y.; Chen, R.; Yu, Y.; Cui, X. Antiviral effects of sophoridine against coxsackievirus B3 and its pharmacokinetics in rats. Life Sci. 2006, 78, 1998-2005. [CrossRef]

132. Bleasel, M.D.; Peterson, G.M. Emetine, Ipecac, Ipecac, Alkaloids and analogues as potential antiviral agents for coronaviruses. Pharmaceuticals 2020, 13, 51. [CrossRef] [PubMed]

133. Amoros, M.; Fauconnier, B.; Girre, R.L. In vitro antiviral activity of a saponin from Anagallis arvensis, Primulaceae, against herpes simplex virus and poliovirus. Antivir. Res. 1987, 8, 13-25. [CrossRef]

134. Simões, C.M.; Amoros, M.; Girre, L. Mechanism of antiviral activity of triterpenoid saponins. Phytother. Res. 1999, 13, 323-328. [CrossRef]

135. Pu, X.; Ren, J.; Ma, X.; Liu, L.; Yu, S.; Li, X.; Li, H. Polyphylla saponin I has antiviral activity against influenza A virus. Int. J. Clin. Exp. Med. 2015, 8, 18963.

136. Bahbah, E.I.; Negida, A.; Nabet, M.S. Purposing saikosaponins for the treatment of COVID-19. Med. Hypotheses 2020, 140, 109782. [CrossRef]

137. Yan, Y.M.; Shen, X.; Cao, Y.K.; Zhang, J.J.; Wang, Y.; Cheng, Y.X. Discovery of anti-2019-nCoV agents from Chinese patent drugs via docking screening. Hypothesis 2020. [CrossRef]

138. Teponno, R.B.; Kusari, S.; Spiteller, M. Recent advances in research on lignans and neolignans. Nat. Prod. Rep. 2016, 33, 1044-1092. [CrossRef]

139. Huang, R.L.; Huang, Y.L.; Ou, J.C.; Chen, C.C.; Hsu, F.L.; Chang, C. Screening of 25 compounds isolated from Phyllanthus species for anti-human hepatitis B virus in vitro. Phytother. Res. 2003, 17, 449-453. [CrossRef]

140. Liu, S.; Wei, W.; Shi, K.; Cao, X.; Zhou, M.; Liu, Z. In vitro and in vivo anti-hepatitis B virus activities of the lignan niranthin isolated from Phyllanthus niruri L. J. Ethnopharmacol. 2014, 155, 1061-1067. [CrossRef] 
141. Soto-Acosta, R.; Bautista-Carbajal, P.; Syed, G.H.; Siddiqui, A.; DelAngel, R.M. Nordihydroguaiaretic acid (NDGA) inhibits replication and viral morphogenesis of dengue virus. Antivir. Res. 2014, 109, 132-140. [CrossRef]

142. Syed, G.H.; Siddiqui, A. Effects of hypolipidemic agent nordihydroguaiaretic acid on lipid droplets and hepatitis C virus. Hepatology 2011, 54, 1936-1946. [CrossRef]

143. Merino-Ramos, T.; de Oya, N.J.; Saiz, J.C.; Martín-Acebes, M.A. Antiviral activity of nordihydroguaiaretic acid and its derivative tetra-O-methyl nordihydroguaiaretic acid against West Nile virus and Zika virus. Antimicrob. Agents Chemother. 2017, 61, e00376-17. [CrossRef]

144. Wang, S.; Le, T.Q.; Kurihara, N.; Chida, J.; Cisse, Y.; Yano, M.; Kido, H. Influenza virus-cytokine-protease cycle in the pathogenesis of vascular hyperpermeability in severe influenza. J. Infect. Dis. 2010, 202, 991-1001. [CrossRef]

145. Oyegunwa, A.O.; Sikes, M.L.; Wilson, J.; Scholle, F.; Laster, S.M. Tetra-O-methyl nordihydroguaiaretic acid (Terameprocol) inhibits the NF-KB-dependent transcription of TNF- $\alpha$ and MCP-1/CCL2 genes by preventing RelA from binding its cognate sites on DNA. J. Inflamm. 2010, 7, 59. [CrossRef]

146. Pollara, J.J.; Laster, S.M.; Petty, I.T. Inhibition of poxvirus growth by Terameprocol, a methylated derivative of nordihydroguaiaretic acid. Antivir. Res. 2010, 88, 287-295. [CrossRef] [PubMed]

147. Chen, H.; Teng, L.; Li, J.N.; Park, R.; Mold, D.E.; Gnabre, J.; Hwu, J.R.; Tseng, W.N.; Huang, R.C. Antiviral activities of methylated nordihydroguaiaretic acids. 2. Targeting herpes simplex virus replication by the mutation insensitive transcription inhibitor tetra-O-methyl-NDGA. J. Med. Chem. 1998, 41, 3001-3007. [CrossRef] [PubMed]

148. Gnabre, J.N.; Brady, J.N.; Clanton, D.J.; Ito, Y.; Dittmer, J.; Bates, R.B.; Huang, R.C. Inhibition of human immunodeficiency virus type 1 transcription and replication by DNA sequence-selective plant lignans. Proc. Natl. Acad. Sci. USA 1995, 92, 11239-11243. [CrossRef] [PubMed]

149. Khanna, N.; Dalby, R.; Tan, M.; Arnold, S.; Stern, J.; Frazer, N. Phase I/II clinical safety studies of terameprocol vaginal ointment. Gynecol. Oncol. 2007, 107, 554-562. [CrossRef]

150. Gao, Y.; Dong, X.; Kang, T.G. Activity of in vitro anti-influenza virus of arctigenin. Chin. Tradit. Herb. Drugs 2002, 33, $724-725$.

151. Fu, L.; Xu, P.; Liu, N.; Yang, Z.; Zhang, F.; Hu, Y. Antiviral effect of arctigenin compound on influenza virus. Tradit. Chin. Drug Res. Clin. Pharmacol. 2008, 4.

152. Hayashi, K.; Narutaki, K.; Nagaoka, Y.; Hayashi, T.; Uesato, S. Therapeutic effect of arctiin and arctigenin in immunocompetent and immunocompromised mice infected with influenza A virus. Biol. Pharm. Bull. 2010, 33, 1199-1205. [CrossRef] [PubMed]

153. Schröder, H.C.; Merz, H.; Steffen, R.; Müller, W.E.; Sarin, P.S.; Trumm, S.; Schulz, J.; Eich, E. Differential in vitro anti-HIV activity of natural lignans. Z. Für Nat. 1990, 45, 1215-1221. [CrossRef] [PubMed]

154. Eich, E.; Pertz, H.; Kaloga, M.; Schulz, J.; Fesen, M.R.; Mazumder, A.; Pommier, Y. -Arctigenin as a lead structure for inhibitors of human immunodeficiency virus type-1 integrase. J. Med. Chem. 1996, 39, 86-95. [CrossRef] [PubMed]

155. Kuo, Y.C.; Kuo, Y.H.; Lin, Y.L.; Tsai, W.J. Yatein from Chamaecyparis obtusa suppresses herpes simplex virus type 1 replication in HeLa cells by interruption the immediate-early gene expression. Antivir. Res. 2006, 70, 112-120. [CrossRef]

156. Wang, Y.; Wang, X.; Xiong, Y.; Kaushik, A.C.; Muhammad, J.; Khan, A.; Dai, H.; Wei, D.Q. New strategy for identifying potential natural HIV-1 non-nucleoside reverse transcriptase inhibitors against drug-resistance: An in silico study. J. Biomol. Struct. Dyn. 2019, 30, 1-5. [CrossRef]

157. Chen, H.; Liu, P.; Zhang, T.; Gao, Y.; Zhang, Y.; Shen, X.; Li, X.; Shen, W. Effects of diphyllin as a novel V-ATPase inhibitor on TE-1 and ECA-109 cells. Oncol. Rep. 2018, 39, 921-928. [CrossRef] [PubMed]

158. Nesmelova, E.F.; Razakova, D.M.; Akhmedzhanova, V.I.; Bessonova, I.A. Diphyllin from Haplophyllum alberti-regelii, H. bucharicum, and H. perforatum. Chem. Nat. Compd. 1983, 19, 608. [CrossRef]

159. Sørensen, M.G.; Henriksen, K.; Neutzsky-Wulff, A.V.; Dziegiel, M.; Karsdal, M.A. Diphyllin, a novel and naturally potent V-ATPase inhibitor, abrogates acidification of the osteoclastic resorption lacunae and bone resorption. J. Bone Min. Res. 2007, 22, 1640-1648. [CrossRef]

160. Martinez-Lopez, A.; Persaud, M.; Chavez, M.P.; Zhang, H.; Rong, L.; Liu, S.; Wang, T.T.; Sarafianos, S.G.; Diaz-Griffero, F. Glycosylated diphyllin as a broad-spectrum antiviral agent against Zika virus. EBioMedicine 2019, 47, 269-283. [CrossRef]

161. Chen, H.W.; Cheng, J.X.; Liu, M.T.; King, K.; Peng, J.Y.; Zhang, X.Q.; Wang, C.H.; Shresta, S.; Schooley, R.T.; Liu, Y.T. Inhibitory and combinatorial effect of diphyllin, a v-ATPase blocker, on influenza viruses. Antivir. Res. 2013, 99, 371-382. [CrossRef]

162. Susplugas, S.; Hung, N.V.; Bignon, J.; Thoison, O.; Kruczynski, A.; Sévenet, T.; Guéritte, F. Cytotoxic arylnaphthalene lignans from a Vietnamese acanthaceae, Justicia p atentiflora. J. Nat. Prod 2005, 68, 734-738. [CrossRef]

163. Zhang, H.J.; Rumschlag-Booms, E.; Guan, Y.F.; Liu, K.L.; Wang, D.Y.; Li, W.F.; Cuong, N.M.; Soejarto, D.D.; Fong, H.H.; Rong, L. Anti-HIV diphyllin glycosides from Justicia gendarussa. Phytochemistry 2017, 136, 94-100. [CrossRef]

164. Yang, Z.; Wang, Y.; Zheng, Z.; Zhao, S.; Zhao, J.I.; Lin, Q.; Li, C.; Zhu, Q.; Zhong, N. Antiviral activity of Isatis indigotica root-derived clemastanin B against human and avian influenza A and B viruses in vitro. Int. J. Mol. Med. 2013, 31, 867-873. [CrossRef]

165. Liu, G.T. Bicyclol: A novel drug for treating chronic viral hepatitis B and C. Med. Chem. 2009, 5, 29-43. Available online: https:/ / www.ingentaconnect.com/content/ben/mc/2009/00000005/00000001/art00005. (accessed on 12 July 2020). [CrossRef]

166. Zhang, J.T. New drugs derived from medicinal plants. Therapie 2002, 57, 137-150.

167. Ruan, B.; Wang, J.W.; Bai, X.L. Comparison of bicyclol therapy for patients with genotype B and C of hepatitis B virus. Zhonghua shi yan he lin chuang bing du xue za zhi=Zhonghua shiyan he linchuang bingduxue zazhi=Chin. J. Exp. Clin. Virol. 2007, 21, 366-368. 
168. Liu, C.H.; Jassey, A.; Hsu, H.Y.; Lin, L.T. Antiviral activities of silymarin and derivatives. Molecules 2019, 24, 1552. [CrossRef]

169. Song, J.H.; Choi, H.J. Silymarin efficacy against influenza A virus replication. Phytomedicine 2011, 18, 832-835. [CrossRef]

170. Cui, Q.; Du, R.; Liu, M.; Rong, L. Lignans and their derivatives from plants as antivirals. Molecules 2020, 25, 183. [CrossRef]

171. Wen, C.C.; Kuo, Y.H.; Jan, J.T.; Liang, P.H.; Wang, S.Y.; Liu, H.G.; Lee, C.K.; Chang, S.T.; Kuo, C.J.; Lee, S.S.; et al. Specific plant terpenoids and lignoids possess potent antiviral activities against severe acute respiratory syndrome coronavirus. J. Med. Chem. 2007, 50, 4087-4095. [CrossRef] [PubMed]

172. Vilhelmova-Ilieva, N.; Galabov, A.S.; Mileva, M. Tannins as antiviral agents. Tannins-structural properties, biological properties and current knowledge. Alfredo Aires 2019. [CrossRef]

173. Yang, C.M.; Cheng, H.Y.; Lin, T.C.; Chiang, L.C.; Lin, C.C. The in vitro activity of geraniin and 1,3,4,6-tetra-O-galloyl- $\beta$-d-glucose isolated from Phyllanthus urinaria against herpes simplex virus type 1 and type 2 infection. J. Ethnopharmacol. 2007, 110, 555-558. [CrossRef] [PubMed]

174. Notka, F.; Meier, G.; Wagner, R. Concerted inhibitory activities of on HIV replication In vitro and ex vivo. Antivir. Res. 2004, 64, 93-102. [CrossRef] [PubMed]

175. Lin, L.T.; Chen, T.Y.; Chung, C.Y.; Noyce, R.S.; Grindley, T.B.; McCormick, C.; Lin, T.C.; Wang, G.H.; Lin, C.C.; Richardson, C.D. Hydrolyzable tannins (chebulagic acid and punicalagin) target viral glycoprotein-glycosaminoglycan interactions to inhibit herpes simplex virus 1 entry and cell-to-cell spread. J. Virol. 2011, 85, 4386-4398. [CrossRef]

176. Vilhelmova, N.; Jacquet, R.; Quideau, S.; Stoyanova, A.; Galabov, A.S. Three-dimensional analysis of combination effect of ellagitannins and acyclovir on herpes simplex virus types 1 and 2. Antivir. Res. 2011, 89, 174-181. [CrossRef]

177. Vilhelmova-Ilieva, N.; Jacquet, R.; Quideau, S.; Galabov, A.S. Ellagitannins as synergists of ACV on the replication of ACV-resistant strains of HSV 1 and 2. Antivir. Res. 2014, 110, 104-114. [CrossRef]

178. Vilhelmova-Ilieva, N.; Sirakov, I.; Jacquet, R.; Deffieux, D.; Quideau, S.; Galabov, A.S. Antiviral activities of ellagitannins against bovine herpesvirus 1, suid alphaherpesvirus 1 and caprine herpesvirus 1. J. Vet. Med. Anim. Health 2020, 12, 139-143. [CrossRef]

179. Vilhelmova-Ilieva, N.; Deffieux, D.; Quideau, S. Castalagin: Some aspects of the mode of anti-herpes virus activity. Ann. Antivir. Antiretrovir. 2018, 2, 004-007. [CrossRef]

180. Wahyuni, T.S.; Azmi, D.Z.; Permanasari, A.; Adianti, M.; Lydia, T.; Widiandani, T.; Aoki, U.C.; Widyawaruyanti, A.; Fuad, A.; Hak, H. Anti-viral activity of Phyllanthus niruri against hepatitis c virus. Malays. Appl. Biol. 2019, 48, 105-111.

181. Dhama, K.; Karthik, K.; Khandia, R.; Chakraborty, S.; Munjal, A.; Latheef, S.K.; Kumar, D.; Ramakrishnan, M.A.; Malik, Y.S.; Singh, R.; et al. Advances in designing and developing vaccines, drugs, and therapies to counter Ebola virus. Front. Immunol. 2018, 9, 1803. [CrossRef] [PubMed]

182. Munjal, A.; Khandia, R.; Dhama, K.; Sachan, S.; Karthik, K.; Tiwari, R.; Malik, Y.S.; Kumar, D.; Singh, R.K.; Iqbal, H.M.N.; et al. Advances in developing therapies to combat Zika virus: Current knowledge and future perspectives. Front. Microbiol. 2017, 8, 1469. [CrossRef] [PubMed]

183. Singh, R.K.; Dhama, K.; Chakraborty, S.; Tiwari, R.; Natesan, S.; Khandia, R.; Munjal, A.; Vora, K.S.; Latheef, S.K.; Karthik, K.; et al. Nipah virus: Epidemiology, pathology, immunobiology and advances in diagnosis, vaccine designing and control strategies-A comprehensive review. Vet. Q. 2019, 39, 26-55. [CrossRef]

184. Chen, L.; Hu, C.; Hood, M.; Zhang, X.; Zhang, L.; Kan, J.; Du, J. A novel combination of vitamin C, curcumin and glycyrrhizic acid potentially regulates immune and inflammatory response associated with coronavirus infections: A perspective from system biology analysis. Nutrients 2020, 12, 1193. [CrossRef]

185. Dhama, K.; Sharun, K.; Tiwari, R.; Dadar, M.; Malik, Y.S.; Singh, K.P.; Chaicumpa, W. COVID-19, an emerging coronavirus infection: Advances and prospects in designing and developing vaccines, immunotherapeutics, and therapeutics. Hum. Vaccin Immunother. 2020, 16, 1232-1238. [CrossRef] [PubMed]

186. Gangal, N.; Nagle, V.; Pawar, Y.; Dasgupta, S. Reconsidering traditional medicinal plants to combat COVID-19. AIJR 2020. Available online: https:/ / preprints.aijr.org/index.php/ap/preprint/view/34 (accessed on 24 August 2020).

187. Malik, Y.S.; Kumar, N.; Sircar, S.; Kaushik, R.; Bhat, S.; Dhama, K.; Gupta, P.; Goyal, K.; Singh, M.P.; Ghoshal, U.; et al. Coronavirus disease pandemic (COVID-19): Challenges and a global perspective. Pathogens 2020, 9, E519. [CrossRef] [PubMed]

188. Rastogi, S.; Pandey, D.N.; Singh, R.H. COVID-19 Pandemic: A pragmatic plan for Ayurveda intervention. J. Ayurveda Integr. Med. 2020. [CrossRef]

189. Vellingiri, B.; Jayaramayya, K.; Iyer, M.; Narayanasamy, A.; Govindasamy, V.; Giridharan, B.; Ganesan, S.; Venugopal, A.; Venkatesan, D.; Ganesan, H.; et al. COVID-19: A promising cure for the global panic. Sci. Total Environ. 2020, $725,138277$. [CrossRef]

190. Yang, Y.; Islam, M.S.; Wang, J.; Li, Y.; Chen, X. Traditional Chinese medicine in the treatment of patients infected with 2019-new coronavirus (SARS-CoV-2): A review and perspective. Int J. Biol. Sci. 2020, 16, 1708-1717. [CrossRef] [PubMed]

191. Yatoo, M.I.; Hamid, Z.; Parray, O.R.; Wani, A.H.; Ul Haq, A.; Saxena, A.; Patel, S.K.; Pathak, M.; Tiwari, R.; Malik, Y.S.; et al. COVID-19-Recent advancements in identifying novel vaccine candidates and current status of upcoming SARS-CoV-2 vaccines. Hum. Vaccin Immunother. 2020, 1-14. [CrossRef]

192. Dhama, K.; Chakraborty, S.; Tiwari, R.; Verma, A.K.; Saminathan, M.; Amarpal, Y.M.; Nikousefat, Z.; Javdani, M.; Khan, R.U. A concept paper on novel technologies boosting production and safeguarding health of humans and animals. Res. Opin. Anim. Vet. Sci. 2014, 4, 353-370. 
193. Abd El-Hack, M.E.; Alagawany, M.; Farag, M.R.; Arif, M.; Emam, M.; Dhama, K.; Sarwar, M.; Sayab, M. Nutritional and pharmaceutical applications of nanotechnology: Trends and advances. Int. J. Pharm. 2017, 13, 340-350.

194. Prasad, M.; Lambe, U.P.; Brar, B.; Shah, I.; Manimegalai, J.; Ranjan, K.; Rao, R.; Kumar, S.; Mahant, S.; Khurana, S.K.; et al. Nanotherapeutics: An insight into healthcare and multi-dimensional applications in medical sector of the modern world. Biomed. Pharm. 2018, 97, 1521-1537. [CrossRef]

195. Borkotoky, S.; Banerjee, M. A computational prediction of SARS-CoV-2 structural protein inhibitors from Azadirachta indica (Neem). J. Biomol. Struct. Dyn. 2020, 1-7. [CrossRef] [PubMed]

196. Manoharan, Y.; Haridas, V.; Vasanthakumar, K.C.; Muthu, S.; Thavoorullah, F.F.; Shetty, P. Curcumin: A wonder drug as a preventive measure for COVID19 management. Indian J. Clin. Biochem. 2020, 35, 373-375. [CrossRef]

197. Zahedipour, F.; Hosseini, S.A.; Sathyapalan, T.; Majeed, M.; Jamialahmadi, T.; Al-Rasadi, K.; Banach, M.; Sahebkar, A. Potential effects of curcumin in the treatment of COVID-19 infection. Phytother. Res. 2020, 34, 2911-2920. [CrossRef]

198. Straughn, A.R.; Kakar, S.S. Withaferin A: A potential therapeutic agent against COVID-19 infection. J. Ovarian Res. 2020, 13, 1-5. [CrossRef]

199. Pandey, P.; Khan, F.; Kumar, A.; Srivastava, A. Screening of potent inhibitors against 2019 novel coronavirus (Covid-19) from Allium sativum and Allium cepa: An in silico approach. Biointerface Res. Appl. Chem. 2020, 11, 7981-7993. [CrossRef]

200. Meireles, D.; Gomes, J.; Lopes, L.; Hinzmann, M.; Machado, J. A review of properties, nutritional and pharmaceutical applications of Moringa oleifera: Integrative approach on conventional and traditional Asian medicine. Adv. Tradit. Med. 2020, 17, 1-21. [CrossRef]

201. Russo, M.; Moccia, S.; Spagnuolo, C.; Tedesco, I.; Russo, G.L. Roles of flavonoids against coronavirus infection. Chem. Biol. Interact. 2020, 109211. [CrossRef] [PubMed]

202. Su, H.; Yao, S.; Zhao, W.; Li, M.; Liu, J.; Shang, W.; Xie, H.; Ke, C.; Gao, M.; Yu, K.; et al. Discovery of baicalin and baicalein as novel, natural product inhibitors of SARS-CoV-2 3CL protease in vitro. bioRxiv 2020. [CrossRef]

203. Awad, R.; Arnason, J.T.; Trudeau, V.; Bergeron, C.; Budzinski, J.W.; Foster, B.C.; Merali, Z. Phytochemical and biological analysis of skullcap (Scutellaria lateriflora L.): A medicinal plant with anxiolytic properties. Phytomedicine 2003, 10, 640-649. [CrossRef] [PubMed]

204. Basha, S.H. Corona virus drugs-a brief overview of past, present and future. J. Peer Sci. 2020, 2, e1000013. [CrossRef]

205. Salehi, B.; Kumar, N.V.; Şener, B.; Sharifi-Rad, M.; Kılıç, M.; Mahady, G.B.; Vlaisavljevic, S.; Iriti, M.; Kobarfard, F.; Setzer, W.N.; et al. Medicinal plants used in the treatment of human immunodeficiency virus. Int. J. Mol. Sci. 2018, 19, 1459. [CrossRef]

206. Bosch-Barrera, J.; Martin-Castillo, B.; Buxó, M.; Brunet, J.; Encinar, J.A.; Menendez, J.A. Silibinin and SARS-CoV-2: Dual targeting of host cytokine storm and virus replication machinery for clinical management of COVID-19 patients. J. Clin. Med. 2020, 9, 1770. [CrossRef]

207. Orhan, I.E.; Deniz, F.S. Natural products as potential leads against coronaviruses: Could they be encouraging structural models against SARS-CoV-2? Nat. Prod. Bioprospecting 2020, 10, 171-186. [CrossRef] [PubMed]

208. Laskar, M.A.; Choudhury, M.D. Search for therapeutics against COVID 19 targeting SARS-CoV-2 papain-like protease: An in silico study. ChemRxiv 2020. [CrossRef]

209. Lou, C.; Zhu, Z.; Zhao, Y.; Zhu, R.; Zhao, H. Arctigenin, a lignan from Arctium lappa L., inhibits metastasis of human breast cancer cells through the downregulation of MMP-2/-9 and heparanase in MDA-MB-231 cells. Oncol. Rep. 2017, 37, 179-184. [CrossRef]

210. Shen, L.; Niu, J.; Wang, C.; Huang, B.; Wang, W.; Zhu, N.; Deng, Y.; Wang, H.; Ye, F.; Cen, S.; et al. High-throughput screening and identification of potent broad-spectrum inhibitors of coronaviruses. J. Virol. 2019, 93, e00023. [CrossRef] [PubMed]

211. Zhang, Y.N.; Zhang, Q.Y.; Li, X.D.; Xiong, J.; Xiao, S.Q.; Wang, Z.; Zhang, Z.R.; Deng, C.L.; Yang, X.L.; Wei, H.P.; et al. Gemcitabine, lycorine and oxysophoridine inhibit novel coronavirus (SARS-CoV-2) in cell culture. Emerg. Microbes Infect. 2020, 9, 1170-1173. [CrossRef] [PubMed]

212. Gurung, A.B.; Ali, M.A.; Lee, J.; Farah, M.A.; Al-Anazi, K.M. Unravelling lead antiviral phytochemicals for the inhibition of SARS-CoV-2 Mpro enzyme through in silico approach. Life Sci. 2020, 255, 117831. [CrossRef] [PubMed]

213. Ma, G.; Yasunaga, J.I.; Ohshima, K.; Matsumoto, T.; Matsuoka, M. Pentosan polysulfate demonstrates anti-human T-cell leukemia virus type 1 activities in vitro and in vivo. J. Virol. 2019, 93, e00413-19. [CrossRef] [PubMed] 